\title{
Factors Leading to Customer Retention in the High Volume- Low Volume Service Context: Evidence from the Mobile Service Industry
}

\author{
Boon Liat Cheng \\ Department of Marketing, Sunway University, Selangor, Malaysia \\ Sanjaya Singh Gaur \\ Department of Marketing, Sunway University, Selangor, Malaysia \\ Rezuan Abdul Rahim \\ Department of Marketing, Sunway University, Selangor, Malaysia
}

\begin{abstract}
Service convenience has undoubtedly gain substantial recognition for both goods and service industries within recent years towards forging an enduring competitive advantage. Considering heightened market expectations in the mobile service industry, importance of capitalizing on relevant elements is highlighted to retain, further strengthen users' loyalty. Technological advancement has then created opportunity for differentiation in the area of reachability, particularly on the transaction convenience and access convenience of specified mobile service. Alongside product involvement, brand image and perceived value as hypothesized predictors of users' allegiance towards a mobile service, this study explored factors which influence customers' loyalty and propensity to leave within the mobile service industry. Convenience sampling approach was hereby implemented, following distribution of close-ended questionnaires among 400 respondents. Data analysis was then conducted through employment of the SEM AMOS software. As such, results obtained discovered product involvement, perceived value, transaction convenience and access convenience being direct predictors of both dependent variables; with the exception of brand image which doesn't affect propensity to leave, despite being a significant antecedent to customers' loyalty. Additionally, transaction convenience was revealed as an active moderator to the impact of perceived value on (i) customer loyalty, and (ii) propensity to leave. Centred on the transactional aspect in the mobile service industry, more effective service marketing strategies can be developed through gained insights from this research, with excelling sustainable customer retentions.
\end{abstract}

Keywords: Customer Retention, Access Convenience, Transaction Convenience, Brand Image, Product Involvement, Perceived Value 


\section{Introduction}

In today's world, technology has evolved so much that it affects the way we perform our daily tasks. From shopping experiences, communication, information search, to commercial activities like making bill payments, tasks can be performed with a simple swipe, thanks to such technological advancement. Among others, mobile devices have gained significant popularity among consumers. In 2016 alone, the Industry Performance Report by MCMC (Malaysian Communications and Multimedia Commission) has recorded Malaysians to stand at a total of 141 devices per 100 inhabitants. This indicates that roughly $40 \%$ of the population carried more than 1 mobile devices individually (MCMC, 2016). Further tabulated through data collected by the MCMC, $51.5 \%$ of the Malaysian population ranked mobile phone as an "important" necessity, followed by $44.8 \%$ of them who deemed the device "moderately important"; which, denotes the remaining minority (\%) sees it being rather "not important". Further analysis has, then, found switching trend among 10\% of mobile service users to a different service provider, following their first-year engagement within the respective providers.

In conjunction to the evolution of mobile devices, advancement has also been noticeable in payment systems of mobile services, where acclamation and acceptance are gained over time. Mobile payment can be described as any transaction on a mobile handset, where ownership of money changes hands (Pope, Pantages, Enachescu, Dinshaw, Joshlin, Stone, Austria, \& Seal, 2011). It began as a substitute transaction for customers to complete their payments, as to derive a solution in combating congestions within offline channels such as retail stores and banks. With its increased popularity, functions of mobile payment have extended to other forms of payment activities including online purchase, fund transfer, bill payment, as well as charity donation.

Such market opportunities have led to increase in mobile service providers, mobile device manufacturers, and mobile application developers to continuously offer compatible mobile service packages and innovative mobile devices. Particularly, market shares among the Malaysian mobile service providers demonstrate somewhat minimal variations. As observed, Digi Communication is leading the market with $37 \%$ in market share, followed by Maxis at 34\% and Celcom at 29\% (The Edge, 2019). Despite this oligopoly environment, companies have experienced circumstance of business instability in areas of profitability, sales revenue, employee retention, customer retention and cash flow (Connelly, Lee, Tihanyi, Certo, \& Johnson, 2019). Likewise, customer recruitment and retention have become more complicated and costly. Ever since the early 2000s, emphasis was shifted towards developing and increasing customer loyalty within the industry, in view of ensuring continuous growth as part of a company's competitive advantage (So, King, Sparks, \& Wang, 2016). The intensity has grown tremendously coming to today's marketplace settings. 
Excellent product and service offerings become a fundamental element towards customer retention; where, failure to meet such expectations often results in customers abandoning their current service provider in favour of another. Consumers are most likely to hold service providers accountable for service failures or dissatisfactions. To minimize such occurrences, service providers strive in innovating their services for enhancing the overall customer experience. An example being payment channels, where interruption of online bill payment due to unstable Internet connection can lead to frustration or dissatisfaction. Relating this to the notion of accountability, there are differing opinions as to which party (the customer or service provider) should be held responsible (Kumar, Sachan, \& Mukherjee, 2017). Yet, this debate from a competitive sustainability perspective further highlights notion of customer centrism, which would suggest accountability to fall towards the side of the service providers. Neglecting users' feedback in this regard can possibly generate an advantage to existing competitors, allowing them to deliver better transactional value. With this, learned prospect should not solely revolve on accountability, but extend upon strategies to deliver greater value for sustaining market competitiveness.

In retrospect, conventional methods would require customers to spend substantial amount of cost, time and energy to perform and complete subscription payments. This being accounted, transaction convenience is seen as a potential key that could help reduce redundancy and promote customer retention (Lemon \& Verhoef, 2016). As mobile devices evolve, payment methods should evolve in tandem such that mobile payments are introduced and taught to consumers. User-friendly mobile payment methods would be a competitive advantage for telco providers, allowing them to improve customer loyalty by highlighting customer centrism. With the construct of service convenience proposed by Berry, Seiders and Grewal (2002) as a basis, ease of payment and reachability are hereby highlighted upon the fore-discussed context; which, placed accountability on transaction convenience and access convenience.

Noted that multiple studies within similar context has focused on the influence of brand image (Ahmad \& Zafar, 2019), product involvement (Rokonuzzaman, Harun, Al-Emran, \& Prybutok, 2020) and perceived value (Peña, Jamilena, \& Molina, 2016) on loyalty and tendency of switching allegiance; yet, not without the mediating effect of satisfaction. Considering mobile service being somewhat transformative technology in a continuous pace, moderators as being proposed by previous researchers have placed primary emphasis on sociodemographic variables including gender, age, qualification, experience, occupation, income level, marital status and lifestyle towards circumstance of service adoption over brand retention (Chawla \& Josh, 2018; Sabine, Klose, \& Ettinger, 2017; Lee, Lee, \& Rha, 2019). While various studies have placed service convenience in the predicting role towards influencing satisfaction, further behavioural intentions (Bi \& Kim, 2020; Chen, Chang, Chen, \& Chen, 2019); the mobile service industry has remained fairly concealed where service convenience is placed in the moderating role, as being sidestepped by other researchers exploring the discussed construct (Ali, Mohd Noor, \& Mahmood, 2016; Kuo, Chang, Chen, \& Hsu, 2012). 
Current scope being placed on investigating importance of transactional accessibility to the mobile service front in Malaysia; this study, thus, aimed to identify the impact of product involvement, brand image, perceived value, access convenience and transaction convenience on level of customer loyalty together with their propensity to leave the providers of mobile service. Herewith, emphasis is extended on evaluating the moderating effects of access convenience and transaction convenience in the relationships between (a) customer loyalty and perceived value, as well as (b) customers' propensity to leave and perceived value in the Malaysian mobile service industry.

\section{Research Questions}

Based on the previously established research gap, the current study was conducted in answering the following research questions:

1. Which of the investigated factors (product involvement, brand image, perceived value, access convenience and transaction convenience) would have a significant impact on customers' loyalty and propensity to leave a mobile service provider?

2. How would transaction convenience moderate the impact of perceived value on customers' loyalty and propensity to leave a mobile service provider?

3. How would access convenience moderate the impact of perceived value on customers' loyalty and propensity to leave a mobile service provider?

\section{Literature Review}

\section{Expectancy Disconfirmation Theory}

Acknowledging the nature of this study, Expectancy Disconfirmation Theory (EDT), as introduced by Oliver $(1977,1980)$, provides significant explanation on the phenomenon that matches expectations to outcomes. Let consumers' perceptions being static, Dissonance Theory highlights resolution of psychological discomfort through re-evaluation of offerings to meet prior expectations (Yi, 1990); yet, Contrast Theory opposed with stating intensification of disparity between expected and actual outcomes shall such existed (Cardozzo, 1965). Accounted for flaws both theories, EDT managed to provide more rigorous view on the fore-mentioned circumstance, which accounted for negative disconfirmation when outcomes fall short of expected services, vice versa (Yüksel \& Yüksel, 2008). It comes without saying, the paradigm has been substantially applied within the service sector, towards determining elements that entail satisfaction (Kim \& Choi, 2019; Zhu, Freeman, \& Cavusgil, 2018). Such was similarly expanded towards the field of mobile services in gauging satisfactionrelated factors (Quoquab, Mohammad, Md Yasin, \& Abdullah, 2018; Hsu, Lin, Chen, \& Suraphatchara, 2019). 
Transcending satisfaction, the proposed theory was adopted in investigating elements influencing persisted intention (Oghuma, Libaque-Saenz, Wong, \& Chang, 2016; Ting, Fam, Cheah, Richard, \& Xing, 2019). In many cases, a sequential relationship is revealed with satisfaction being the antecedent to customer loyalty; while both being directly influenced by the studied independent variables (Mat, Wan, \& Adeyemi, 2018; Wong \& Chang, 2014). With prior belief on existing technology through previous experience, Fan and Suh (2014) further proposed versatility in switched avocation among users shall performance of disruptive development that comes later falls short of their pre-constructed expectation. Understood that such paradigm has been widely applicable in exploring antecedents for endorsements within consumer goods (Chadwick \& Piartrini, 2019; Chen-Yu, Kim, \& Lin, 2017); such has also been apparent towards explaining the customer satisfaction model within personalized occasions (Choi, Moon, \& Kim, 2019); thus, deemed compatible in underlining consumers' ongoing loyalty as per high volume-low-volume products.

In another case, EDT has been adopted in studying smartphone consumer behaviour alongside the Theory of Planned Behaviour (TPB); which, connecting stimulus to customers' responses (Chai, 2019). TPB is known for being the theoretical foundation which effectively describe the tendency of consumers' actual undertakings regarding their formed attitude, societal perceptions and individual's behavioural control (Ajzen, 1991). Surpassing mere consumers' perspectives, behavioural control can be generated at side of the service providers; where, users hold substantial belief that particular provider is reliable in delivering service that meets their underlying expectations (Tan, 2016). With proposition where EDT holds limited capability to illustrate experience-intensive services due to the lack of sufficient prior experience in forming an accurate expectation (Halstead, Hartman, \& Schmidt, 1994; Hill, 1985; Jayanti \& Jackson, 1991), integration of TPB would entail otherwise, with beliefs take on as a foundation towards constructing expected outcomes. Nevertheless, this research has placed more emphasis on effectiveness to retain market share over acquiring new ones. First encounter aside, the current study hereby adapted EDT in exploring variables of service retention, with recognizing existence of readied beliefs through prior exposure.

Figure 1: Theoretical Framework

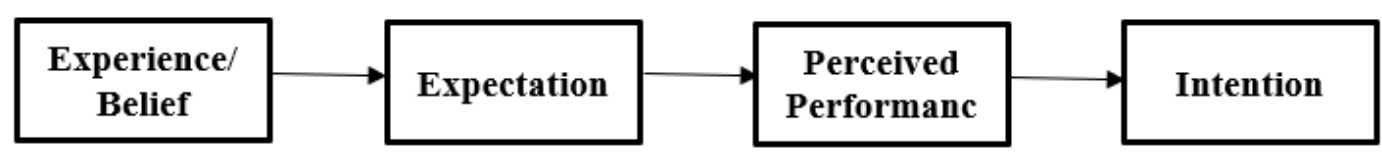

\section{Customer Loyalty}

Fundamentally, customer loyalty refers to the "willingness of someone-a customer, an employee, a friend - to make an investment or personal sacrifice in order to strengthen a relationship" (Reichheld, 2003). As according to Oliver (1999), a customer's level of loyalty from a business perspective describes a customer's continuous belief towards a product/service/company in fulfilling their value proposition, further influences repurchases. Specifically, Zeithaml, Berry and 
Parasuraman (1996) divided loyalty into four stages: (i) cognitive; (ii) affective; (iii) conative; and (iv) action loyalties. Loyalty is hereby highlighted as a complex, multidimensional behaviour influenced by sociodemographic (e.g. income, emotion, age), as well as other internal and external environmental factors. Whereas, Dick and Basu (1994) countered with the concept of "no loyalty", particularly in extremely brand competitive environments where customers frequently switch brands in fulfilment of individual requirements.

Loyalty as proposed in temporal stages by Oliver (1999), cognitive loyalty is primarily achieved, where loyalty is formed through new encounters with a brand where judgment is solely founded upon performance over emotional attachment. Manifestation via continuous positive brand delivery would then lead to subsequent stage of affective loyalty, which accounts for emotional attachment formed through pleasant brand experience, while carrying degree of switching tendency. Shall this persisted, conative loyalty would be formed, which represents commitment where cognitive and affective loyalty support consumers' thinking process. In turn, it results intentions to make repeat purchases, even when actual purchases aren't guaranteed. Thus, emphasis is simultaneously placed on action loyalty being the final stage, when repeat purchases are realized through decisions supported by cognitive, affective, and conative elements. Noted by Oliver (1999), in-depth commitment is achieved in this stage, with contributions provided by customers in form of financial profitability.

With intense competitions over larger market shares, customer retention is undeniably crucial in lowering marketing and operational costs of attracting new customers; which, translates higher profitability (Cham, Ng, Lim, \& Cheng, 2018; Cheah, Ting, Cham, \& Memon, 2019; Cheng, Mansori, \& Cham, 2014; Chevalier, Dover, \& Mayzlin, 2018). Noted that satisfaction, value and switching cost have prevailed as significant predictors to loyalty towards specific mobile service (Quoquab, Abdullah, \& Jihad, 2016). Continuous subscription can also be potentially motivated by contractual obligation, limited market choices, and psychological fear of monetary cost implications, besides satisfaction (Biscaia, Rosa, Moura e Sa, \& Sarrico, 2017). Indisputably, periodical understanding of customer loyalty is crucial following changing perceptions of product involvement, brand image, perceived value, transaction convenience and access convenience for being predictors of customer loyalty towards mobile service providers, further industrial sustainability and growth (Capistrano, 2013; Dunuwille \& Pathmini, 2016; Ling, Yang, \& Jun, 2013). As such, this study investigated customer loyalty in terms of making desirable recommendations, motivation of positive word-of-mouth, as well as repurchase intention. Herewith, the impact of product involvement, brand image, perceived value, transaction convenience and access convenience on loyalty was investigated.

\section{Propensity to Leave}

In general, propensity to leave refers to the perceived likelihood that a partner will terminate the relationship in the reasonably near future (Morgan \& Hunt, 1994; Bluedorn, 1982). A study by Keaveney (1995) covering 45 types of services further 
acknowledged several factors contributing a customer's propensity to leave, which identified failures of core services including mistakes, billing errors and service catastrophes ( $44 \%$ of respondents) being the biggest contributor on switching propensity to other brands. Additionally, service failures have been identified as the second most significant contributor to customer's propensity to leave. Being acknowledged as unpleasant interactions between customers and the service providers, service encountered failures include employees' impoliteness, unresponsiveness and incompetence when serving customers.

As such, propensity to leave would be significantly influenced by pricing and service convenience (Pansari \& Kumar, 2017). Yet, Eshghi, Haughton and Topi (2007) contrasted with suggesting switching cost as the primary contributing factor within the wireless telephone market in the United States. In this case, a large number of customers refused to switch homage due to concern on a lost in acquaintances' contact information, regardless of satisfaction level. Switching cost is, thus, involved considerations for loss of social bonds, setup costs, functional risks, attractiveness of alternatives, and loss of special treatment benefits. Alternatively, Pirc (2006), in highlighting relationship significance between competitive offerings, propensity to leave, and customer loyalty, defined propensity to leave as "the expressed likelihood by the customer of positively reacting to competitors' offers." With covering mobile phones as part of a consumption system that influence loyalty and switching intentions, Pirc (2006) has proposed mobile service usage to exert a curvilinear effect on propensity to leave. Attention is hereby brought to the importance of displaying service price in addressing customers from a pricing perspective over that of mobile phone price; and, the limited influence of subscripted duration towards retaining existing customers. Nevertheless, re-acquiring left customers would be a task of heightened difficulties.

Increased prevalence of telecommunication usage has enabled convenience among customers to switch between competing brands shall expectations are not fulfilled. Herewith, accounted factors would include crossover features, cost involved, and possibility of losing contact information during the switching process (Oyeniyi \& Abiodun, 2010); call rates and network coverage (Sathish, Kumar, \& Jeevanantham, 2011); as well as customer service, quality of service, and usage costs (Karani \& Fraccastoro, 2010; Lien, Cao, \& Zhou, 2017). Particularly, the current study evaluates influence of product involvement, brand image, perceived value, transaction convenience and access convenience on propensity to leave and customer loyalty in the Malaysian mobile service industry.

\section{Brand Image}

Brand image is related to the evaluation and perception of a brand's identity, reputation and other brand-related aspects. Its formation is based upon customers' experience and interactions upon a particular brand over time; in turn, provides guidance towards their decision-making process (Veloutsou, Daskou, \& Daskou, 2004; Nguyen \& Leblanc, 2001). Such is more apparent during a product's trial stage, 
as a reputable brand would imply lesser risk in making a purchase among customers (Cham, Lim, \& Aik, 2015; Cham, Lim, Aik, \& Tay, 2016). Further highlighted by Nguyen and Leblanc (2001), a brand's image is a set of associations collected over time in minds of consumers, which creates attitudes and beliefs that yield positive consumer-brand connections. Noted by Aaker (1991), consumers prefer famously branded products due to comfort generated from reliability. Confirmed by Drezner (2002), shared attitude and self-image, or the desire to achieve self-image as offered by the brand can potentially drive consumptions.

However, awareness and knowledge would be the foothold prior development of image or association (Wijaya, 2011). Awareness in acknowledging existence of a brand is primarily aimed when a brand is initially launched. Consistent delivery of brand attributes would then produce consumer understanding beyond recognition, by developing brand knowledge. Perceptions and associations follow through continuous and intensive communication, as well as specific experiences towards understanding products' abstract concepts; which, entails image. As such, several components that form brand image include personal elements that constitute stimuli deliberately created by the brand's owner, and environmental elements that cover technical product attributes as controlled by the organization (Walters, 1974). Yet, a brand's image isn't constant, where repositioning can be done by changing the brand's attributes, dependent over the evolving consumer landscape on demographical tastes and preferences (Dunuwille \& Pathmini, 2016).

Study by Ofori, Boakye and Narteh (2018) on mobile phone services has indicated brand image as antecedent to preference and brand loyalty. In fact, positive experiences on reliability, service quality, and overall performance are some factors building favorable brand image among mobile phone consumers (Dunuwille \& Pathmini, 2016). Such positive perceptions would further affect expectations and brand loyalty, which influence brand-related decisions (Jumiati \& Norazah, 2015). Acknowledged that negative experiences hinder future repurchases within today's demanding consumers, mobile service providers remain very keen to compete within this market (The Sun Daily, 2019). This study, therefore, examines influence of brand image on customer loyalty and the propensity to leave their mobile service providers, with the first and second hypotheses postulated:

H1 Brand image has a positive influence on customer loyalty.

H2 Brand image has a negative influence on customer's propensity to leave.

\section{Product Involvement}

According to Blackwell, Miniard and Engel (2001), product involvement is defined as the "ongoing commitment of a customer's interest in purchasing a certain product or service". It highlights the extent to which decision is made based on individual goal, basic values, and self-concept. Mittal and Lee (1989) further suggested involvement as a state of mental motivation in which a person carries when performing certain 
tasks. Simply, it highlights the level of interest a consumer has towards a product (Mittal \& Lee, 1989). With Sun, Cheng, and Cui (2016) stating the influence of cognitive and affective involvements towards consumption-based behavioural intentions; the variable accounts for factors such as feelings, thoughts, and even behaviours.

Following simultaneous evolutions within the mobile industry, degree of involvement experiences consequential changes. In particular, significance of mobile services lies within connectivity that enabled executions of daily errands (MCMC, 2016). While product involvement potentially stimulates interest, such involvement does not guarantee a purchase (Harrigan, Evers, Miles, \& Daly, 2018). Yet, its impact in navigating change adoption as implemented by specific suppliers among customers should not be neglected, through increased product and price transparency (Nguyen \& Nguyen, 2019). Societal norms accounted, heightened product involvement, through increased product-related knowledge, would lower the influence of societal perceptions on consumption intentions (Chao \& Chen, 2016). This being said, increased customer involvement would entail more product-related discovery, inclusive of possible weaknesses that may outweigh its strengths.

In one hand, information-based involvement has overshadowed brand image through having inversed influence on the relationship between perceived value and satisfaction towards particular mobile service (Calvo-Porral \& Nieto-Mengotti, 2019). In another, product involvement has shown to predict customers' loyalty in the field of mobile applications, through evaluating individual's relevance and informationseeking orientation (Sarkas \& Sarkas, 2019). Product involvement is being currently referred to the intensity of consumer attitudes and behaviours applied towards learning about a particular mobile service provider (Capistrano, 2013). The influence of product involvement on customer's propensity to leave, as well as their level of loyalty in the Malaysian mobile service industry are hereby evaluated, with the third and fourth hypotheses formulated:

H3 Product involvement has a positive influence on customer loyalty.

H4 Product involvement has a negative influence on customer's propensity to leave.

\section{Perceived Value}

Perceived value consisted subjective view of the value receive over what is give (Sweeney \& Soutar, 2001). It covers several dimensions including social, emotional, monetary value and quality (Sweeney \& Soutar, 2001). Expanded upon, this concept was mainly specified into product needs, low price, price paid against product's quality, and offering received for the price paid (Zeithaml, 1988). Understandably, value perception should be customer-oriented towards meeting needs and preferences; with perceived value being described as consumers' overall evaluation of product or 
service utility upon the value-exchange perceptions (Zeithaml, 1988). As such, a balance between total values offered against total cost paid is being emphasized.

An increase in perceived value, which enriches relationships, can also increase the level of attitudinal loyalty. Being a multi-dimensional construct, Sanchez, Callarisa, Rodriguez and Moliner (2006) have suggested perceived value as a combination of social, emotional, and functional dimensions; whereas, Yang, Song, Chen, and Xia (2017) argued that it merely constitutes emotional and cognitive elements. In the context of mobile services, value is derived from differentiated service plans, additional features, data subscriptions, and family packages (Tung, 2013). Breaking down, Andriyani, Wibowo, Novalita, Rahayu, Kusumojanto, Sulistyowati, and Sudarwanto (2017) further proposed aspects of quality, cognation, monetary, behavioural, and market position, which constituted perceived value as single variable, to play substantial role towards customer retention; with monetary value being the least influential aspect. Perceived value, with benefits through practicality, pleasure and societal perception, is, thus, determined to precede intentions for product acquisition (Yang, Yu, Zo, \& Choi, 2016). More so, perceived value towards a particular service holds tendency in developing satisfaction, further commitments to the service provider (Karjaluoto, Shaikh, Saarijärvi, Saraniemi, 2019). Such has been associated to the generation of trust, with the discussed factor being a direct antecedent alongside quality and price (Berraies, Yahia, \& Hannachi, 2017). Consecutively, it entails customer loyalty and retention (Bauer, Falk, \& Hammerschmidt, 2006; Leppaniemi, Karjaluoto, \& Saarijarvi, 2017; Eggert \& Ulaga, 2002; Sirdeshmukh, Singh, \& Sabol, 2002).

In totality, perceived value denotes the "worth" that services possess in the minds of customers, which impacts their purchasing behaviours. Multiple studies have been recently discussed on the relationship between value, product commitment, and brand loyalty (Lee, Hsu, \& Fu, 2014; Zhang, Zhou, Su, \& Zhou, 2013). As such, value created within a service, alongside perceived quality, ownership period and developed loyalty, would directly affect customers' retentions (Chattha, Naqi, \& Haroon, 2016; Darley \& Luethge, 2019). This study extends its investigations with the influences of perceived value on customer loyalty and the propensity to leave a mobile service provider. The fifth and sixth hypotheses are, thus, postulated:

H5 Perceived value has a positive influence on customer loyalty.

H6 Perceived value has a negative influence on customer's propensity to leave.

\section{Access Convenience}

Being a dimension of service quality as proposed by Berry et al. (2002), access convenience involves consumer perceptions of time and effort required to initiate and consume a service. Such accounts for efforts needed for a service request, further participation efforts in operating the service. Herewith, elements such as service locations, operating hours, parking availability, and contact points are being 
represented as the access convenience offered by a service provider. Additionally, Seiders, Berry and Gresham (2000) proposed inclusion of service delivery capacity and the option of making appointments as factors separating space and time.

Typically, access convenience would play a more significant role for inseparable services, like taxi services and product repair (Pham, 2011). Often, these cases would captivate the indivisible nature, whereby consumer's absence would render the service inaccessible. Self-service technologies, thus, come into play, solving the inseparability problem by allowing service consumptions without having reliance on the service provider; which, promotes greater accessibility and access convenience. Circumstances like that of mobile billing and banking would then enable boundless accessibility in terms of locations and schedules, while promoting heightened flexibility (Ling et al., 2013). Beauchamp and Ponder (2010), Lim and Cham (2015) then suggested importance of access convenience in the context of online purchases, with user-friendliness and exploration proficiency of product navigations beyond limitations of physical locations (Ling et al., 2013). User-friendliness and exploratory proficiency in terms of diminished time and efforts would then yield customers' repeat patronage towards online platforms (Mahapatra, 2017). Questioning effectiveness of contact mediums and platforms in affecting customers' returned behaviours, this study identifies significance of access convenience towards loyalty and the propensity to leave with the seventh and eighth hypotheses being postulated:

H7 Access convenience has a positive influence on customer loyalty.

H8 Access convenience has a negative influence on customer's propensity to leave.

Remarked, accessibility has proven to be a significant predictor towards customers' perceptions upon online services (Durup, Surujlal, \& Redda, 2014). In congruence to robust branding, locational accessibility would be benefitted towards strengthening loyalty among customers (Lim, Cham, \& Sia, 2018; Swoboda, Berg, Schramm-Klein, \& Foscht, 2013). Seeing that ease of accessing online transaction sites is being considered to yield greater retention on e-banking, loyalty can be forged through cultivating routine usage of such service among existing followers (Al-Hawary \& Hussein, 2017; Kajenthiran, Rajumesh, \& Umanakenan, 2018; Konalingam, Ratnam, Sivapalan, \& Naveen, 2017). Convenience has often been a stepping stone that motivates customers towards positive evaluations of self-servicing technologies, in terms of accuracy, speed, further prospective intentions (Collier \& Kimes, 2012). Whereas, convenience, alongside perceived practicality and ease of use have shown significance towards positive consumers' attitude on technology adoption; which, entails continual consumption intention (Chang, Yan, \& Tseng, 2012). This, however, is rebutted by Konalingam et al. (2017) in influencing customer loyalty, despite accessibility remains a significant predictor. Further unveiled by Umashankar, Bhagwat and Kumar (2017), growing behavioural loyalty would denote increased customers' value-based evaluations on experienced services, with lowered emphasis on benefits and convenience. While Berry et al. (2002) placed a blurred line in 
explaining access convenience as a combined variable, the previous statement revealed potential moderating influence of such variable on the relationship between perceived value and functional-oriented retention. The ninth and tenth hypotheses are hereby established:

H9 Access convenience moderates the influence of perceived value on customer loyalty.

H10 Access convenience moderates the influence of perceived value on customer's propensity to leave.

\section{Transaction Convenience}

Transaction convenience, being a branch to service convenience, focuses on the convenience afforded by customers when completing their payment transactions (Lemon \& Verhoef, 2016). It focuses on the actions that consumers must take to secure the right to use a service. With this, a poorly designed transaction infrastructure would undeniably result in long waiting time for customers (Larson, 1987). Even in the online settings, two-thirds of Internet shoppers would abandon their cart during the checkout page in cases of slow sites (Cimino, 2000). Deemed the most undesirable stage across the consumption journey, loss of sales can occur. Expanded upon, transaction convenience consisted of simple and convenient online payment, flexible payment methods, and the absence of difficulty in completing a purchase; which, shall neglected would cause abandonment of purchasing process (Ling et al., 2013; Jih, 2007; Kaura, Prasad, \& Sharma, 2015). Technical difficulties and lack of payment alternatives during online purchases would then entail customer's tendency to desert the transaction (Rajamma, Paswan, \& Hossain, 2009).

Nevertheless, disparity between online and offline settings is apparent, where offline transaction convenience emphasizes minimal interval towards purchase completion; whereas, online transaction convenience constitutes simple and flexible payment methods (Ling et al., 2013). Knowing that the mobile service industry provides both online and offline payment platforms, changing elements utilized to support payment methods remained investigatory in affecting customers' allegiance. The eleventh and twelfth hypotheses are, thus, formulated:

H11 Transaction convenience has a positive influence on customer loyalty.

H12 Transaction convenience has a negative influence on customer's propensity to leave.

Extended upon, convenience in the transactional process has demonstrated significance towards moderating customers' tendency to repurchase, overshadowing that of service experience and perceived value (Gupta \& Kim, 2007). More so in the digital-interconnectivity front, customers have ranked transaction convenience above transaction security in transforming intentions to actual consumption behaviours 
within online platforms (Indiani \& Fahik, 2020). Attention is brought to the aspect of user-friendliness as an accounted factor that influence adoption of transaction-related technology; while favourable experience would entail propensity of future usage (Liébana-Cabanillas, Sánchez-Fernández, \& Muñoz-Leiva, 2014). While transaction experience might not exert sufficient influence towards altering element of satisfaction, such has shown to be significant in constructing trust within the digital environment (Jin \& Park, 2006). In another case, contradicted findings have been obtained within similar context when it comes to connecting customers' satisfaction to loyalty (Ali, Noor, \& Mahmood, 2016). Nonetheless, convenience is viewed an essential benefit for mobile payments; in turn, being the predictor to consumption intentions (Gao \& Waechter, 2017). Noted that offered ease of transaction within the online settings can reduce customers' tendency to seek, further pursue better alternatives (Anderson \& Srinivasan, 2003); the potential moderating role of transaction convenience should not be overlooked. The thirteenth and fourteenth hypotheses are hereby postulated:

H13 Transaction convenience moderates the influence of perceived value on customer loyalty.

H14 Transaction convenience moderates the influence of perceived value on customer's propensity to leave.

\section{Conceptual Framework}

Based on the literature review, a conceptual framework has been constructed, as shown in Figure 2 below.

Figure 2: Conceptual Framework

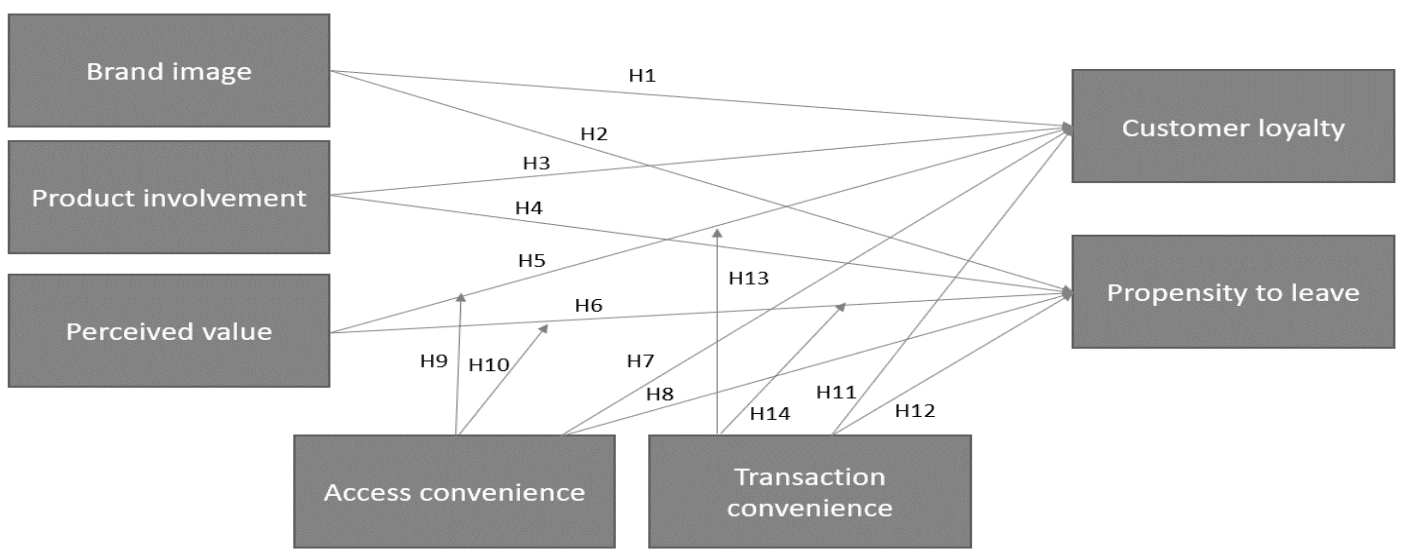




\section{Research Methodology}

This study was empirical in nature and employed quantitative methods of analysis. Seven variables had been employed to test the hypothesized relationships in the conceptual framework. These variables are product involvement, brand image, perceived value, access convenience, transaction convenience, customer loyalty and propensity to leave. A survey in the form of a questionnaire was used for data collection. The items and scales in the questionnaire were adopted from related literature relating to ensure enhanced validity (Lemon \& Verhoef, 2016; Nguyen \& Leblanc, 2001; Sirdeshmukh et al., 2002; Harris \& Goode, 2004; Morgan \& Hunt; 1994). A pilot test with 100 participants was conducted to further confirm the questionnaire's reliability. All the items in the questionnaire achieved reliability score (Cronbach Alpha) more the 0.70 and all the questions are well understood by the respondents. This action was deemed necessary in making previously overlooked corrections and improvements, further avoid ambiguous questions and biased responses amid actual data collection (Memon, Ting, Ramayah, Chuah, \& Cheah, 2017). The initial questionnaire was, thus, revised upon received feedback and reviews.

In conjunction to the ideal of Industry 4.0, mass customization is embraced within the mobile service industry towards fulfilling users' individual demand (Wan, Yi, Li, Zhang, Wang, \& Zhou, 2016). Such was, thus, deemed compatible as per research context of the current study in representing high-volume low-volume product, as it accounts for users' operational patterns (Marquez, Gramaglia, Fiore, Banchs, Ziemlicki, \& Smoreda, 2017); further forges differentiations and decision-making upon customers' requests (Kang, Park, Lee, \& Rho, 2017; Mourtzis, Doukas, \& Vandera, 2016); despite retaining fair service generalization. Herewith, convenience sampling was used with questionnaires distributed across 400 customers of respective mobile service providers in Malaysia, which yielded 392 were usable responses. Statistical tools in the SEM-AMOS package were then used to analyse items' reliability and hypothesized relationships as per the research model.

\section{Key Findings}

\section{Demographic Characteristics of Respondents}

As seen in Table 1, there is a rather balanced distribution of respondents in terms of gender (46.4\% male and 53.6 female). Most of the respondents are aged between 20 and $39(54.3 \%)$, followed by those aged 40 to 59 (39\%). In terms of monthly income, the majority are in the RM2,000 to RM4,999 range (66.1\%). As for educational background, almost half of the respondents have a bachelor's degree or equivalent $(45.2 \%)$. 
Table 1: Respondents' demographic profile

\begin{tabular}{llcc}
\hline \multicolumn{1}{c}{ Variable } & \multicolumn{1}{c}{ Classification } & Frequency & Percentage (\%) \\
\hline Gender & Male & 182 & 46.4 \\
Age & Female & 210 & 53.6 \\
& Below 19 years old & 16 & 4.1 \\
20-39 years old & 213 & 54.3 \\
Ethnicity & 40-59 years old & 153 & 39.0 \\
& Above 60 years old & 10 & 2.6 \\
\multirow{5}{*}{ Monthly Income } & 115 & 29.3 \\
& Malay & 260 & 66.3 \\
& Chinese & 17 & 4.3 \\
Education & Indian & 1 & 0.3 \\
& Less than RM1,999 & 259 & 66.1 \\
& RM2,000-RM4,999 & 117 & 29.8 \\
& RM5,000-RM9,999 & 15 & 3.8 \\
& Above RM10,000 & 35 & 8.9 \\
& Primary school or below & 65 & 16.6 \\
& Secondary school & 89 & 22.7 \\
& Certificate or Diploma & 177 & 45.2 \\
& Bachelor's Degree & 6 & 1.5 \\
& Master's Degree & 17 & 4.3 \\
& Doctoral Degree & 3 & 0.8 \\
& Professional Qualifications & 206 & 52.6 \\
& Employed for Wages & 154 & 39.3 \\
& Self-employed & 27 & 6.9 \\
& Professional & 5 & 1.3 \\
\hline & Student & &
\end{tabular}

\section{Confirmatory Factor Analysis}

Confirmatory factor analysis was used in the current study to examine both the discriminant and convergent validity of the selected constructs. A model can be considered fit if the normed chi-square value $\left(\chi^{2} / \mathrm{df}\right)$ is less than 3 , root mean square error of approximation (RMSEA) is less than 0.08, goodness of fit (GFI) exceeds 0.90, Tucker-Lewis index (TLI) exceeds 0.90, comparative fit index exceeds 0.90, adjusted goodness of fit index exceed 0.90, and parsimony normed fit index (PNFI) exceeds 0.50 (Hair, Black, Babin, Anderson, \& Tatham, 2010). The measurement model for this study was of good fit; the results of the confirmatory factor analysis yielded the following values for the constructs named above: $\chi^{2} / \mathrm{df}=329$, RMSEA $=$ $0.033, \mathrm{GFI}=0.923, \mathrm{TLI}=0.972, \mathrm{CFI}=0.975, \mathrm{AGFI}=0.905$, and $\mathrm{PNFI}=0.801$.

Table 2: Convergent Validity Results

\begin{tabular}{ccccc}
\hline & Items & Factor loading & $\begin{array}{c}\text { Average Variance } \\
\text { Extracted (AVE) }\end{array}$ & $\begin{array}{c}\text { Composite } \\
\text { Reliability }\end{array}$ \\
\hline Customer loyalty & 4 & $0.739-0.791$ & 0.503 & 0.802 \\
Access convenience & 3 & $0.678-0.926$ & 0.707 & 0.877 \\
Transaction convenience & 3 & $0.611-0.818$ & 0.538 & 0.775 \\
Brand Image & 3 & $0.828-0.857$ & 0.588 & 0.810 \\
Perceived value & 3 & $0.768-0.854$ & 0.705 & 0.878 \\
Propensity to leave & 3 & $0.645-0.799$ & 0.550 & 0.785 \\
Product involvement & 4 & $0.667-0.867$ & 0.623 & 0.936 \\
\hline
\end{tabular}


Convergent validity was then assessed based on suggestions by Hair et al. (2010), in fulfilment of three main criteria, namely (1) the standardized factor loading values for all items should have a loading estimate of at least 0.60 , (2) the average variance extracted (AVE) for all the constructs should be greater than 0.70, and (3) the composite reliability value should exceed 0.70 . As shown in Table 2 , the standardized factor loading values for all measurement items are above 0.60, AVEs for all constructs exceed 0.50 , and composite reliability exceeds 0.70 . This has, thus, established the convergent validity of this study.

On discriminant validity, assessment was based on suggestions by Fornell and Larcker (1981), where convergent validity is achieved if the square AVE for each construct is greater than the shared variance between the constructs. Results in Table 3 further show that the current constructs have achieved discriminant validity as the values of the correlation between constructs are less than that of the squared AVEs. The following section then discusses results for the path analysis.

Table 3: The Results of Discriminant Validity

\begin{tabular}{lrrrrrrr}
\hline & $\mathbf{1}$ & $\mathbf{2}$ & $\mathbf{3}$ & $\mathbf{4}$ & $\mathbf{5}$ & $\mathbf{6}$ & $\mathbf{7}$ \\
\hline Customer loyalty & $\mathbf{0 . 7 1 0}$ & & & & & & \\
Access convenience & 0.156 & $\mathbf{0 . 8 4 1}$ & & & & & \\
Transaction convenience & 0.275 & 0.115 & $\mathbf{0 . 7 3 4}$ & & & & \\
Brand Image & 0.244 & -0.008 & 0.318 & $\mathbf{0 . 7 6 7}$ & & & \\
Perceived value & 0.208 & -0.042 & 0.144 & 0.184 & $\mathbf{0 . 8 4 0}$ & & \\
Propensity to leave & -0.259 & -0.222 & -0.186 & -0.004 & -0.136 & $\mathbf{0 . 7 4 2}$ & \\
Product involvement & 0.157 & 0.114 & 0.093 & 0.068 & 0.028 & -0.297 & $\mathbf{0 . 7 8 9}$ \\
\hline
\end{tabular}

Notes: 1. The off-diagonal entries (in italics) represent the variance shared between constructs. 2. The diagonal entries (in bold) represent the squared root average variance extracted by the construct.

\section{Structural Model and Hypothesis Testing}

Findings from the analysis have shown that the structural model is of good fit with values $\chi^{2} / \mathrm{df}=330, \mathrm{RMSEA}=0.033, \mathrm{GFI}=0.922, \mathrm{TLI}=0.971, \mathrm{CFI}=0.974, \mathrm{AGFI}=$ 0.904 , and PNFI $=0.803$. The path analysis in Table 4 and Figure 3 shows that all independent variables were found to have impact on customer loyalty. Brand image, access convenience, perceived value and product involvement have presented significant positive influences on customer loyalty. Whereas, access convenience $(\beta=$ $0.115)$, brand image $(\beta=0.139)$, product involvement $(\beta=0.153)$, and perceived value $(\beta=0.1)$ were identified to be associated with customer loyalty at a 95 percent confidence level. 
Table 4: Results of Path Analysis

\begin{tabular}{lccc}
\hline Hypothesized Path & $\begin{array}{c}\text { Standardized } \\
\text { Beta }(\boldsymbol{\beta})\end{array}$ & $\begin{array}{c}\text { Critical } \\
\text { Ratio }\end{array}$ & Significance \\
\hline H1: Brand Image $\rightarrow$ Customer loyalty & 0.139 & $2.285^{*}$ & Yes \\
H2: Brand Image $\rightarrow$ Propensity to leave & 0.117 & $1.281^{\text {n.s. }}$ & No \\
H3: Product involvement $\rightarrow$ Customer loyalty & 0.153 & $2.003^{*}$ & Yes \\
H4: Product involvement $\rightarrow$ Propensity to leave & -0.543 & $-4.475^{* *}$ & Yes \\
H5: Perceived value $\rightarrow$ Customer loyalty & 0.100 & $2.705^{*}$ & Yes \\
H6: Perceived value $\rightarrow$ Propensity to leave & -0.125 & $-2.246^{*}$ & Yes \\
H7: Access convenience $\rightarrow$ Customer loyalty & 0.115 & $2.308^{*}$ & Yes \\
H8: Access convenience $\rightarrow$ Propensity to leave & -0.238 & $-3.118^{*}$ & Yes \\
H1: Transaction convenience $\rightarrow$ Customer loyalty & 0.184 & $2.754^{*}$ & Yes \\
H12: Transaction convenience $\rightarrow$ Propensity to leave & -0.232 & $-2.312^{*}$ & Yes \\
\hline
\end{tabular}

Notes: $* *$ and $*$ denote significant at $99 \%$ and $95 \%$ confidence level respectively; n.s. denotes not significant

Figure 3: Results of Path Analysis Generated through AMOS

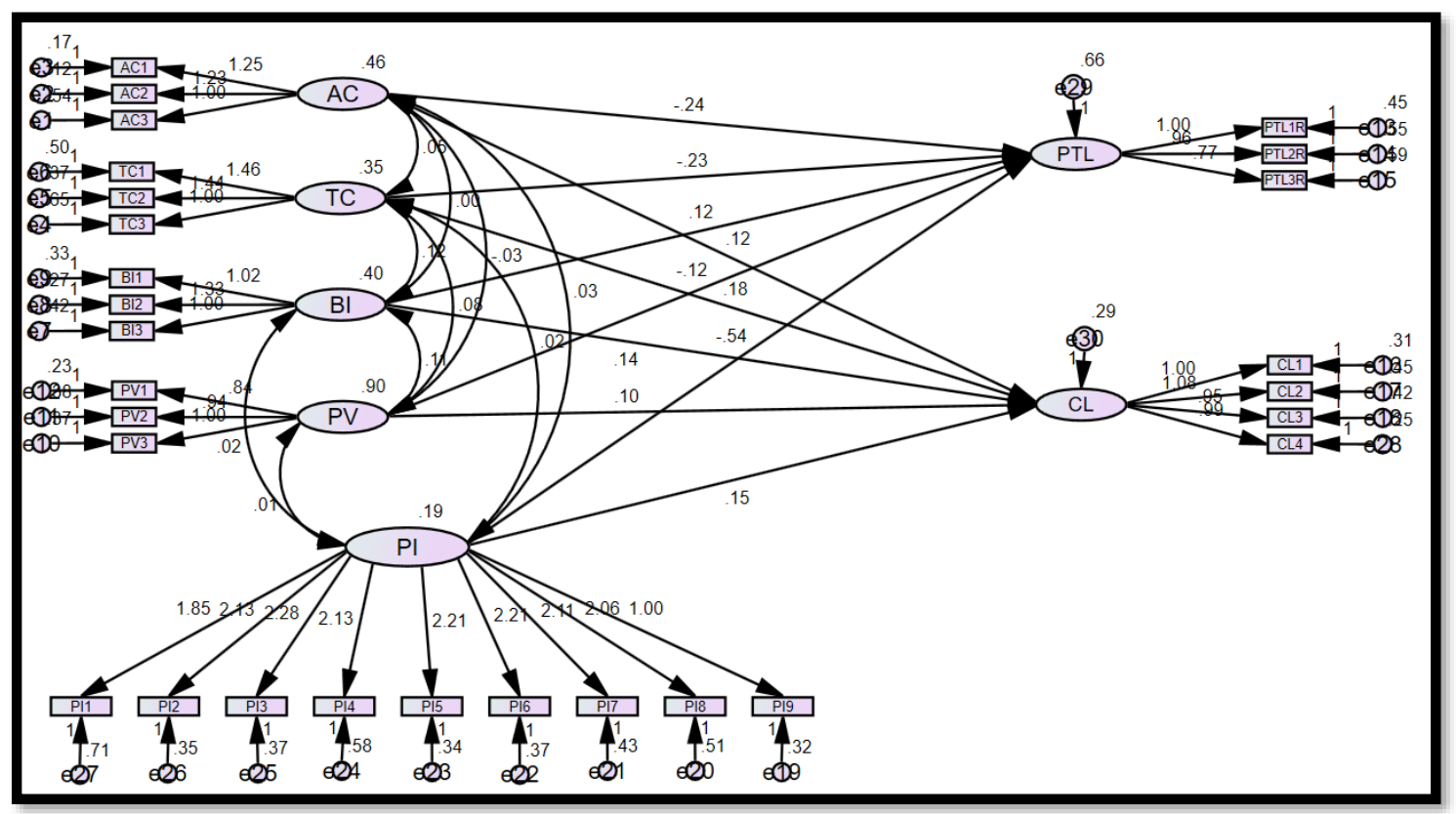

Notes: $\mathrm{AC}=$ Access convenience, $\mathrm{TC}=$ Transaction convenience, $\mathrm{BI}=$ Brand Image, $\mathrm{PV}=$ Perceived value, $\mathrm{PI}=$ Product involvement, $\mathrm{PTL}=$ Propensity to leave, $\mathrm{CL}=$ Customer loyalty

Table 4 also indicates that most independent variables were found to have impact on propensity to leave. Noted that brand image is the sole variable to be insignificant between the current relationships. Product involvement $(\beta=-0.543)$ has shown to have a significant influence on customer propensity to leave at a 99 percent confidence level. Access convenience $(\beta=-0.238)$ and perceived value $(\beta=-0.125)$ were found to be associated with propensity to leave at a 95 percent confidence level. Transaction convenience was found to have impact on both customer loyalty $(\beta=$ $0.184)$ and propensity to leave $(\beta=-0.232)$. 


\section{Moderating Effects of Access Convenience and Transaction Convenience}

The moderating effect of access convenience and transaction convenience was investigated using Hayes' PROCESS Macro for IBM SPSS v24, as it permits analysis of mediation and moderation on complex models. PROCESS (Hayes, 2013) was used with preference towards variance or covariance based structural equation modelling (SEM) to achieve three objectives. Despite varying estimation methods and theories, results from the two alternative analytical techniques are largely identical with differences being rarely substantive (Hayes, Montoya, \& Rockwood, 2017). Whereas, the SEM approach holds some serious limitations on moderation, making PROCESS more preferable (MacKinnon, Coxe, \& Baraldi, 2012). Nonetheless, the investigated research model, consisted of a single moderator whose interaction corresponded to Model 1 in PROCESS, allowed for relative analytical simplicity. The obtained results are as shown in Table 5 and 6 , respectively.

Table 5: Results of Moderating Analysis of Access Convenience

\begin{tabular}{|c|c|c|c|c|c|c|}
\hline & \multicolumn{3}{|c|}{ (Y) Customer Loyalty } & \multicolumn{3}{|c|}{ (Y) Propensity to leave } \\
\hline & $\mathrm{B}$ & $\mathrm{Se}$ & p-value & $\mathrm{B}$ & se & p-value \\
\hline (X) Perceived Value & -0.154 & 0.243 & $0.528^{\text {n.s. }}$ & -0.118 & 0.330 & $0.720^{\text {n.s. }}$ \\
\hline $\begin{array}{ll}(\mathrm{W}) & \text { Access } \\
\text { convenience } & \\
\end{array}$ & -0.164 & 0.237 & $0.488^{\text {n.s. }}$ & -0.033 & 0.321 & $0.917^{\text {n.s. }}$ \\
\hline $\begin{array}{lr}\text { Interaction } & \text { (Perceived } \\
\text { Value X Access } \\
\text { convenience) }\end{array}$ & 0.056 & 0.044 & $0.208^{\text {n.s. }}$ & 0.045 & 0.060 & $0.459^{\text {n.s. }}$ \\
\hline Constant & 5.326 & 1.300 & $0.000 * *$ & 7.209 & 1.195 & $0.000 * *$ \\
\hline & \multicolumn{3}{|c|}{$\mathrm{R}^{2}=0.068 ; \mathrm{F}=9.386, \mathrm{p}$-value $=0.000$} & \multicolumn{3}{|c|}{$\begin{array}{l}\mathrm{R}^{2}=0.048 ; \quad \mathrm{F}=6.563, \mathrm{p}- \\
\text { value }=0.000\end{array}$} \\
\hline
\end{tabular}

Notes: $* *$ and $*$ denote significant at $99 \%$ and $95 \%$ confidence level respectively; n.s. represent not significant

Table 6: Results of Moderating Analysis of Transaction Convenience

\begin{tabular}{|c|c|c|c|c|c|c|}
\hline & \multicolumn{3}{|c|}{ (Y) Customer Loyalty } & \multicolumn{3}{|c|}{$\left(Y_{2}\right)$ Propensity to leave } \\
\hline & $\mathrm{B}$ & $\mathrm{Se}$ & $\mathrm{p}$-value & $\mathrm{B}$ & se & $\mathrm{p}$-value \\
\hline (X) Perceived Value & -0.204 & 0.172 & $0.237^{\text {n.s. }}$ & -0.692 & 0.235 & $0.003 *$ \\
\hline $\begin{array}{l}\text { (W) Transaction } \\
\text { convenience }\end{array}$ & -0.209 & 0.179 & $0.244^{\text {n.s. }}$ & -0.756 & 0.244 & $0.002 *$ \\
\hline $\begin{array}{l}\text { Interaction (Perceived } \\
\text { Value X Transaction } \\
\text { convenience) }\end{array}$ & 0.069 & 0.035 & $0.050^{*}$ & 0.123 & 0.048 & $0.010 *$ \\
\hline Constant & 5.519 & 0.877 & $0.000 * *$ & 7.209 & 1.195 & $0.000 * *$ \\
\hline & \multicolumn{3}{|c|}{$\mathrm{R}^{2}=0.216 ; \mathrm{F}=6.300, \mathrm{p}$-value $=0.000$} & \multicolumn{3}{|c|}{$\begin{array}{l}\mathrm{R}^{2}=0.216 ; \quad \mathrm{F}=6.300, \mathrm{p}- \\
\text { value }=0.000\end{array}$} \\
\hline
\end{tabular}

Notes: $* *$ and $*$ denote significant at $99 \%$ and $95 \%$ confidence level respectively; n.s. represent not significant

Particularly, findings in Table 6 have demonstrated transaction convenience to possess interaction effect on the relationship between perceived value and customer loyalty ( $\mathrm{p}$-value $=0.050)$; and, the relationship between perceived value and propensity to leave $(\mathrm{p}$-value $=0.010)$. Yet, access convenience doesn't have any interaction effect on the hypothesized relationships, as indicated in Table 5. The interaction effect of transaction convenience is further plotted in Figures 4 and 5. As 
seen in Figure 4, the slope of high transaction convenience is steeper than that of medium transaction convenience and low medium transaction convenience. This suggested perceived value to be more strongly associated with customer loyalty for the high transaction convenience group, as compared to the medium and low medium transaction convenience groups. H13 is, thus, supported. In other words, when the transaction convenience of mobile services is greater, the negative relationship of customer's perceived value and customer loyalty towards the current providers of mobile services is weaker.

Figure 4: The Moderation Effect of Transaction Convenience on the Relationship Between Perceived Value and Customer Loyalty

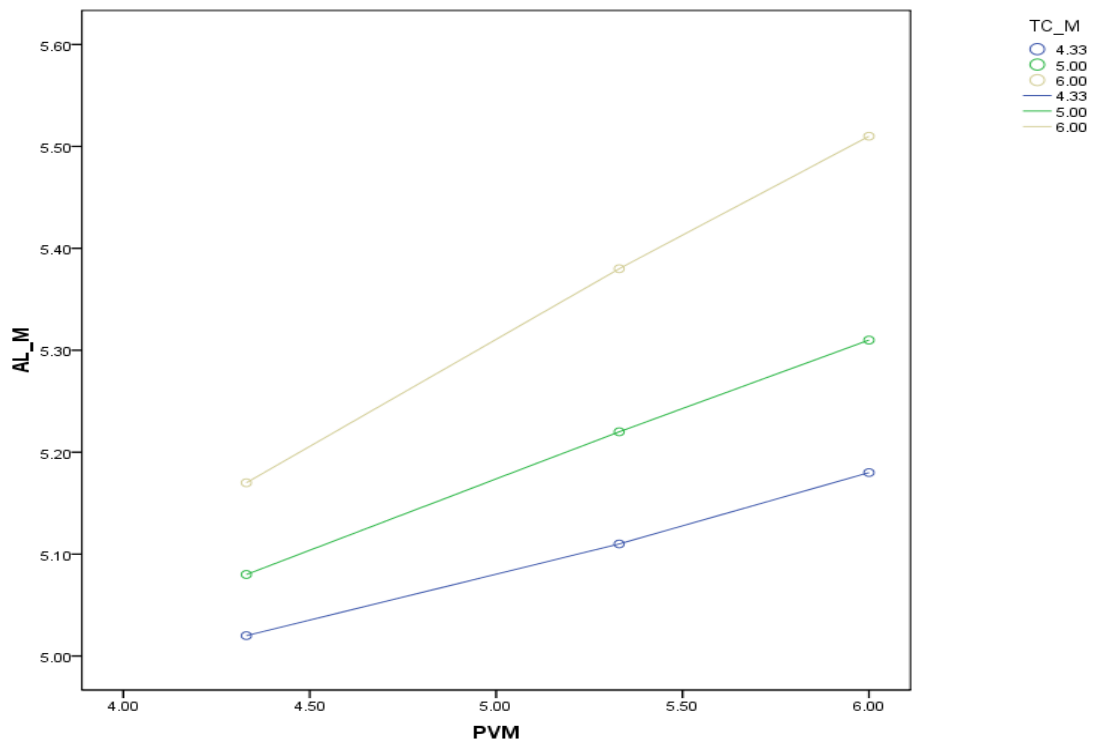

Line 1: high transaction convenience

Line 2: medium transaction convenience

Line 3: low medium transaction convenience

The graph in Figure 5 further shows that the slope of high transaction convenience is steeper than that of medium and low transaction convenience. This suggested that perceived value is more strongly associated with propensity to leave for the high transaction convenience group, as compared to the medium and low medium transaction convenience groups. Hence, H14 is supported. Put differently, negative relationship of customer's perceived value and their propensity to leave the current mobile service providers is weaker when the overall transaction convenience is greater. 
Figure 5: The Moderation Effect of Transaction Convenience on the Relationship Between Perceived Value and Propensity to Leave
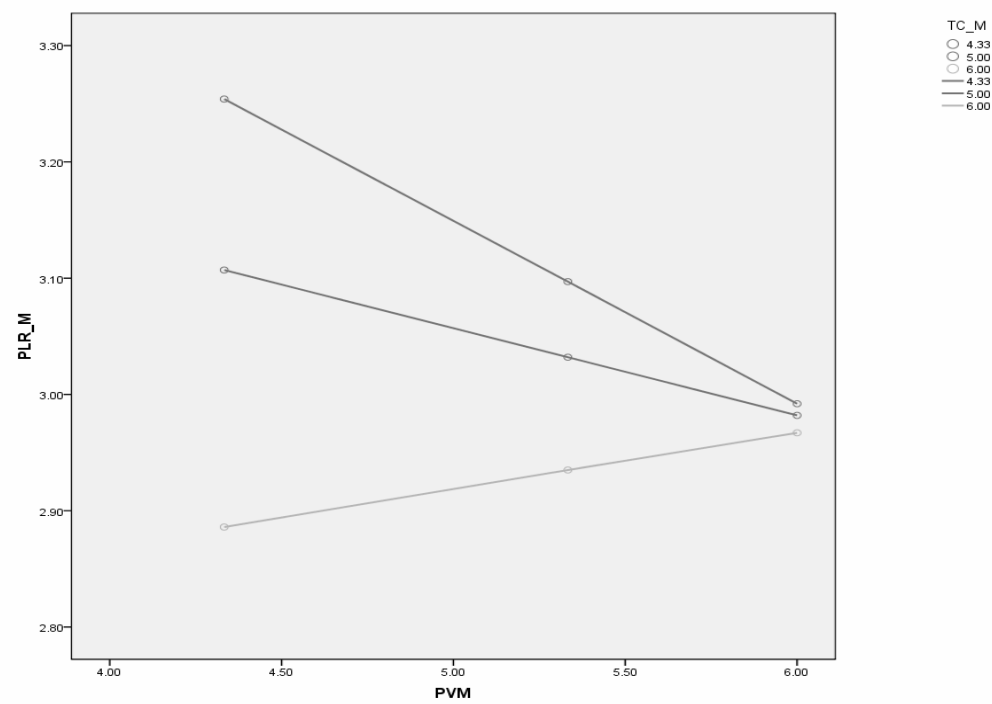

Line 1: high transaction convenience

Line 2: medium transaction convenience

Line 3: low medium transaction convenience

\section{Discussion of Findings}

With reference findings presented in Table 4, product involvement, access convenience, perceived value, brand image and transaction convenience are significant predictors for customer loyalty. This explains the $46.9 \%(\mathrm{R} 2=0.469)$ variance. Simply, these factors will lead to the establishment of loyalty among consumers in the mobile service industry. Upon access convenience, findings obtained have been in consistent to that of Pham, Tran, Misra, Maskeliūnas and Damaševičius (2018), which demonstrated direct influence on customer loyalty. In this case, probability of repeated customers is boosted shall access convenience in terms of location, operating hours and contact points of a mobile service operator is improved (Seiders et al., 2000).

Furthermore, brand image has presented a significant influence towards customer loyalty, as aligned to Baumgarth (2008); Bennett, Härtel and McColl-Kennedy (2005); Biedenbach, Bengtsson and Marell (2015); Glynn (2010); Grant, Juntunen, Juga and Juntunen (2014); Han and Sung (2008). In branding, importance of customer experience arose when discussing brand image due to potential influence of outcome on perceptions towards the brand (Veloutsou et al., 2004; Nguyen \& Leblanc, 2001). Strategy to deliver positive customer experience would require primary understanding of its antecedents, including quality (Helin, 2014), as well as appeal and delivery (Bagga \& Bhatt, 2013); which, would be applicable within the current context.

Product involvement has also been found to positively impact customer loyalty within the mobile service industry in Malaysia. Understood that this variable involves motivation that yield actual actions, considerations are placed upon mere inquiry to actual purchase (Harrigan et al., 2018). Laurent and Kapferer (1985) further broken down the elements of interest, pleasure, risk importance, and risk probability when 
undertaking efforts to enhance customer's product involvement. Their findings have supported the current findings; yet, with variation in predicting factors between diverging contexts. This, thus, highlights the importance of factor relevance towards particular context.

Additionally, customer loyalty can be impacted by perceived value. As consistent to the studies by Ling et al. (2013); Leppaniemi et al. (2017), customers' perceived value in assessing worth of particular services have presented strong impact on their purchase behavior. Such, thus, set expectations towards elements of transaction convenience as basic requirements across mobile services, in acquiring level of loyalty (Cham \& Easvaralingam, 2012; Cheng, Cham Micheal, \& Lee, 2019; Kaura et al., 2015; Ling et al., 2013).

In other cases, investigation made on predictors for propensity to leave has indicated product involvement, access convenience, transaction convenience and perceived value as significant influencers, with the exclusion of brand image. An R2 value of $0.483(48.3 \%)$ is hereby recorded. With significance concerned, declines in each of the predictors would entail customers' incline towards leaving the service provider.

Considering brand image as an insignificant predictor to the propensity to leave, the variable remained crucial in forming positive perception, while indicating capability, reliability, and trustworthiness of a company (Dunuwille \& Pathmini, 2016; Jumiati \& Norazah, 2015). Nonetheless, such insignificance may be contributed by the lack of differentiation among mobile service plans that weaken customers' interests towards brand-related comparison.

With determining perceived value to have an impact on propensity to leave, the findings are in alignment to past literature alongside formation of customer loyalty (Dodds, Monroe, \& Grewal, 1991; Grewal, Monroe, \& Krishnan, 1998; Anderson \& Sullivan, 1993). In addition, the positive impact of product involvement on the propensity to leave is similar to that of Capistrano (2013). With product involvement constitutes the extent to which a consumer attaches importance to certain attributes offered by the service provider, it would impact consumers' perceptions regarding relative costs and benefits associated with purchase decisions (Capistrano, 2013; Zaichkowsky, 1985). An inverse relationship is, therefore, determined between both customer involvement and propensity to leave a mobile service provider.

Despite its effect on customer loyalty, poor access convenience will not influence customers to leave (Consiglio \& Van Osselaer, 2019). Due to minimal efforts required for customers to make online and offline comparisons on mobile service subscription plans (access convenience), the tendency to leave a brand is likely triggered by the perception of consumers towards the branding, value, and level of involvement towards the services purchased.

On the other hand, the moderating effect of access convenience was found to be insignificant between (i) perceived value and customer loyalty, and (ii) perceived value and propensity to leave. Typically, offered access convenience would enhance customer loyalty, while reduce their propensity to leave (e.g. Ling et al., 2013; Pham, 2011). To retain customers would mean continuous enhancement in user-friendliness of navigating the service providers' online platforms. Yet, this research presents 
negligible influence of access convenience on relationships among perceived value, customer loyalty and propensity to leave. This might be contributed by similar customers perceive value on the offered products; while access convenience isn't the main influencer to their subsequent actions. With heightened online accessibility and the products' low contact nature, higher repeat patronage and lower likelihood of leaving is achieved shall tasks can be completed under less time and effort (Mahapatra, 2017).

Whereas, transaction convenience was found to have a positive effect on a customer's propensity to leave, as supported by the studies from Ling et al. (2013); Jih (2007); Kaura et al. (2015). Transaction convenience, being magnitude of customer's effort invested to complete a transaction, would include aspects like time, energy, and mental efforts. Further outlook by Pham et al. (2018) has then placed transaction convenience as a stronger influencer over access convenience towards a customer's propensity to leave. Yet, this contradicts the findings by Pham (2018) which have shown a mixture of results. This, thus, indicates that the importance of both constructs is contextual, where firms would need to make identification upon business relevance.

Moreover, the moderating effect of transaction convenience is significant in the relationships between (i) perceived value and customer loyalty, and (ii) perceived value and propensity to leave. Acknowledged that the presence of transaction convenience would strengthen consumer loyalty, whilst reduce customers' propensity to leave their current mobile service providers; increased transaction convenience would weaken the negative relationship between customers' perceived value and their level of loyalty towards particular service provider. This being said, constant maintenance and upgrade in transaction convenience are needed to enhance customer retention and loyalty within the mobile service industry.

\section{Theoretical Implications}

Noted that Ji and He (2013), upon the study in linking satisfaction, loyalty to intention of repurchase, has demonstrated sequential relationships in between expectancy disconfirmations to intentions for continual subscriptions, built through satisfaction and loyalty (expectancy disconfirmation $\rightarrow$ satisfaction $\rightarrow$ loyalty $\rightarrow$ repurchase intention). Nevertheless, multiple other researchers have discovered mediating impact of satisfaction on customers' loyalty towards particular brands or product offerings (Iqbal, Hassan, \& Habibah, 2018; Lai, Pham, Nguyen, Nguyen, \&, Le, 2019). With EDT ultimately defines disconfirmation between expectation and outcome entails satisfaction (Oliver, 1977; 1980); it merely reflects partial discovery, with the lack of pre-experiential elements within the original theory (Hill, 1985). The statement, thus, placed TPB in a crucial integrated position as it connects evaluations to behavioral intentions (Ajzen, 1991); in this case, attitudinal (perceived value), normative (brand image), and behavioral (product involvement, access convenience, transaction convenience) on loyalty and propensity of switched allegiance.

Such is further differentiated upon attitudinal loyalty, which suggested a grounded commitment for continuous supports towards a brand; and behavioral loyalty, which accounted for convenience over intrinsic devotion (Lai et al., 2019). Outlook is placed on switching cost being a direct predictor to customers' loyalty; the proposal is fairly 
apparent within the investigated industry. Integrating TPB has reflected the forediscussed perspectives; as seen suggested by Hung, Yu, and Chiu (2018) with significance of both attitudinal and behavioral factors, and Othman, Hassan, Ibrahim, Saripin, Sapuan and Roslan (2020) on positive individual evaluation, behavioral control (with inclusion of switching cost), alongside societal perceptions. Current findings have been in-lined to that of Liebana-Cabanillas, Alonso-Dos-Santos, SotoFuentes and Valderrama-Palma (2017), where functional variables (access and transaction convenience) are being highlighted, triggering behavioral (three factors) over minimalistic attitudinal loyalty (one factor), despite limited to the research's framework. Remarked, control beliefs hold substantial influence towards long-term behavioral intentions, surpassing that of direct impact, with existing indirect influence as seen through the moderating effect of transaction convenience.

In another context, contradicting view was presented by Chadwick and Piartrini (2019), where intrinsic quality and convenience have an insignificant influence on intention for repurchase; often due to sociodemographic aspects - spending capability, deviations in consumption patterns, and subjective norms. Reflected through the findings by Sabine et al. (2017); Lee et al. (2019), individual's societal and demographical attributes have not fall short in providing defined insights which deviate behavioral intentions among different social cohorts. The current study explored moderating effects of service convenience, in addition to their direct relationship on behavioral intentions, as an examination on functional over societal elements; where, clarity has been attained in view of the variables' robustness. This, however, doesn't exclude the potential influence of demographical aspects; as exploitable from the well-dispersed respondent base collected within this study.

Additionally, separations can be viewed through differentiations of the dependent variables. While loyalty is a lasting belief where an organization can offer the desired proposition that triggers repurchases (Oliver, 1999); propensity to leave covers the possibility that a customer would terminate a relationship (Morgan \& Hunt, 1994). Deviation is seen though highlighting brand image as a predictor, where it proposed loyalty but not propensity to leave. Again, segmentations come in forms of clusters among existing customers, following the categorization by Ngobo (2017) where different cohorts tend to hold diverse loyalty and switching barriers (e.g. habitual loyals contradict switchers in terms of perceptions towards switching barriers, account for dissimilar variables, further extend of loyalty). With this study placed limelight on theoretical foundation in cause-and-effect between the investigated variables, explaining the constructed framework in totality, researches upon smaller niches would enable further in-depth academic, and application insights.

It is hereby worth noting that the construct for service convenience as proposed by Berry et al. (2003) has been incorporated within this study. Yet, it is not sufficient to state that service innovation in its totality would influence customer retentions within the studied industry. Such is undeniably due to the lack of supportive influence access convenience possesses on the relationships of perceived value towards loyalty and propensity to leave; aside the research's emphasis solely focuses on two out of the five suggested service convenience components. True that conceptual significance would be simpler shall service convenience is classified as a single variable; component-specified studies would provide more targeted exposure, as per previously 
mentioned niches within this field of study. In this case, the robustness of accessibility and transaction factors as independent variables.

\section{Managerial Implications}

Significance of this research project is placed on the impacts of product involvement, brand image, perceived value, access convenience and transaction convenience towards sustainability of the mobile service industry, specifically in differential influences on customers' loyalty and their propensity to leave. By recognizing the significance of these dimensions, more relevant strategies can be designed by mobile service providers to increase their market competitiveness, through competitive differentiations via the investigated factors.

Noted that access and transaction convenience are related to the amount of time and effort required by consumers to initiate a service and complete a transaction (Seiders et al., 2000); the time and effort of the online website or platform setting of mobile service providers would need to be optimized to ensure a seamless user journey. Optimization of site capacity can be done in terms of bandwidth for fast loading times and reduced waiting times. With determining a maximum of 3 clicks would be ideal when setting up an overall user journey (Pham et al., 2018), the number of clicks required prior service consumption should be further reduced.

Despite the fact that brand image isn't significant in influencing the propensity to leave, the notion of customer experience remains crucial to develop a strong brand image. Brand image being the overall perception formed upon elements that a consumer associates with a brand (Veloutsou et al., 2004; Nguyen \& Leblanc, 2001), brand positioning should be constructively executed. Acknowledging quick and easy payment gateway as the brand's objective, minimalistic website and interface designs with short transaction process requirements, coupled with fast loading time would be essential. Brand values should then be communicated prior and after the consumption process (Raj \& Roy, 2015; Vera \& Trujillo, 2017). Advertisements (digital or nondigital) would be important during the consumers' information searching stage in communicating intended brand messages (i.e. what the brand can offer).

Regarding product involvement being the motivation, a customer has towards getting more information on a product/service, key takeaway falls upon increased tendency of acknowledging decision-defining flaws following more obtained information, which affects repeat purchases. In ensuring error-free user journey, functionality of the main pathway a consumer takes should be prioritized before dwelling upon other areas for inspection. Considerations should be allocated on impact of word-of-mouth, where shared errors can be potentially existed (Temkin Group, 2012). Herewith, a dedicated social media team can be formed to monitor any negative feedback, further ensure damage control prior expansive spreading (Kimmel \& Kitchen, 2014).

Perceived value suggests that brands must make a unique, customer-centric proposition whose perceived benefits outweigh the overall costs (Zeithaml, 1988; Sweeney \& Soutar, 2001). While fundamentally brands are required to use customercentrism when developing product value, it is important to constantly update this value (Temkin Group, 2012). With greater connectivity in the digital era, competitors 
would also have increased access to others' propositions and provide similar offerings (Almunia, Benetrix, Eichengreen, O'Rourke \& Rua, 2010). Innovation in product value, thus, enable brand sustainability by having differentiated offering, while deviating from direct competitions. Realized that innovation can be taxing on a company's resources, fresh ideas can be obtained through crowd-sourcing via social media platforms, through incentive-based initiatives (D'Arrigo \& Fachinelli, 2014).

Lastly, focus is placed on understanding the moderating effects of transaction convenience towards the relationship between perceived value and customer loyalty. These effects suggested transaction convenience in reinforcing the product's perceived value, leading to greater potential of repeat purchases. Firms are encouraged to ensure constant responsiveness and efficiency of payment processes or gateway; in turn, allowing quick transactions. An approach is to reduce the extent of details a customer needs to fill prior transactions. Additionally, cookies can also be implemented within digital channels to store customer details to allow automatic form completion. This then speed up the transaction process upon repeat purchases (Pham et al., 2018).

\section{Limitations and Recommendations for Further Research}

The context of this study has been limited to B2C mobile service users. Mobile service companies do provide for $\mathrm{B} 2 \mathrm{~B}$ customers too, but the loyalty of the community is yet to explored despite it having a lower number of corporate customers (though it sees significantly more usage). With technology being a basic component in today's world, the variables identified and tested in this study could be used in other industries including banking, online shopping, medical, etc.

The scope of this study was limited to the loyalty and propensity to leave of mobile service customers. Future research could discuss antecedents of customer loyalty and propensity to leave using a more personal approach linked to emotions and the social behavior of consumers towards current brands they have subscribed to. It can also explore customer perceptions of those brands as opposed to their perceptions towards competing brands. By focusing on the intrinsic factors highlighted and encompassing them into their operations/marketing strategies, mobile service firms could improve their visibility by providing more value, as compared to other service providers which are competing for lower prices.

\section{Conclusion}

To summarize, mobile service providers, being offering high volume-low volume services, should identify and analyze factors affecting customer loyalty alongside their propensity to leave, for the sake of long-term sustainability. Understood that the absence of factors that influence customer loyalty does not necessarily lead to customers leaving a mobile service provider. Loyalty among customers and their propensity to leave can be influenced by several factors including product involvement, access convenience, perceived value and transaction convenience. Transaction convenience further possesses a moderating effect that enhance the relationships of (i) perceived value and customer loyalty; as well as (ii) perceived 
value and propensity to leave. It's worth noting that while declination in brand image would not result switching in allegiance among current users, it should remain an invested factor to reinforce loyalty towards particular mobile service. As such, mobile service providers should work on enhancing their perceived value among customers, in answering the need for competitive differentiation within the industry. Such can be achieved through better connectivity, more flexible data subscription plans, as well as family packages that distinguish a brand from its competitors on the market. Having said that, there stands other factors beyond scope of the current study, with the like of price relevance, marketing efforts, the human elements and extent of customizability that work in congruence towards delivering an all-rounded service experience; which, can be examinable for future researches within similar area of study.

\section{Implications for Asian Business Context}

As highlighted by Nazir, Ali, and Jamil (2016) in their study on the Asian context argued that brand image promote loyalty among customers; yet, it isn't without generation of satisfactions. Conversely, Dunuwille and Pathmini (2016) placed formation of brand image as the consequent of performance-based experiences. While performance-based image retains customers, continuous innovations in mobile service packages shouldn't be overlooked to prevent customers' switches. Aside brand image for the latter circumstance, strategical differentiations via leadership retention, competitive market share acquisition and market niche, as proposed by Nikolaev, Makhotaeva, Malyshev, and Malyuk (2017), are, thus, feasible. Asia being a fairly technological matured market; service leaders can strive through capacity-based innovations to economically improve service offerings, whilst service contenders can pursue niche markets to avoid direct competitions.

Consumers' self-concepts at the center, service customization has proven an essential factor considered towards building brand reputation; in turn, influences customer retentions (Tahir \& Batool, 2018). Attention is hereby brought to the significance of product involvement in generating long-term consumers' patronages. Services can be standardized in mass productions; yet, customizability remains a workable alternative shall customers' desires arose (Ding \& Keh, 2016). Often, customization is viewed as a significance of service quality, which precedes customers' loyalty (Eum, Ahn \& Rhim, 2019). High volume-low-volume services concerned, generalized service selections remain vital as available mobile services that meet common requests; yet, flexibility in personalized services can be an alternative to retain existing customers upon specific occasions in elevating consumers' positive perceptions.

Noteworthy disclosure laid limelight on access convenience and transaction convenience as predictors of customers' retention particularly in the Asian context. Nonetheless, Almarashdeh, Jaradat, Abuhamdah, Alsmadi, Alazzam, Alkhasawneh, and Awawdeh (2019) have further proposed disparity in Asian consumers' perceptions on convenience between different accessed platforms. Such, followed by the currently obtained findings, transpired implications in areas of conveniences. An alternative being increasing the number of platforms accessible by consumers, especially for transactional purposes, so as to maximize convenience among customers. Whereas, other components of service convenience as outlined by Berry et al. (2002) can be potential reinforcements. Expanded upon previous discussions, 
consumers' heterogeneity is deemed impactful towards individual's perceived value upon consumptions (Huang, Mou, See-To \& Kim, 2019). With this in mind, segmentation-based service innovation can possibly ensure improved decision convenience following more targeted service benefits, in accounting for technological foundation of the research's location.

\section{References}

Aaker, D. A., (1991), Managing brand equity, The Free Press, New York.

Ahmad, M., Zafar, U., (2018), "Brand image, satisfaction and trust as a lead to brand loyalty: The mediator effect of brand relationship", Retrieved from https://ssrn.com/abstract=33 02232

Ajzen, I., (1991), "The theory of planned behaviour", Organizational Behaviour and Human Decision Processes, vol. 50, pp. 179-211.

Al-Hawary, S. I. S., \& Hussein, A. J. A., (2017), "The impact of electronic banking services on the customers loyalty of commercial banks in Jordan", International Journal of Academic Research in Accounting, Finance and Management Sciences, vol. 7, no. 1, pp. 50-63.

Ali, N., Noor, N. A. M., \& Mahmood, R., (2016), "The moderating effect of convenience towards the relationship between satisfaction and loyalty in Malaysian banking industry", Mediterranean Journal of Social Sciences, vol. 7, no. 1, pp. 190-196.

Almarashdeh, I., Jaradat, G., Abuhamdah, A., Alsmadi, M., Alazzam, M. B., Alkhasawneh, R., Awawdeh, I., (2019), "The difference between shopping online using mobile apps and website shopping: A case study of service convenience", International Journal of Computer Information Systems and Industrial Management Applications, vol. 11, pp. 151-160.

Almunia, M., Benetrix, A., Eichengreen, B., O’Rourke, K. H., \& Rua, G., (2010), "From great depression to great credit crisis: Similarities, differences and lessons", Economic Policy, vol. 36, no. 62, pp. 219-265.

Anderson, R. E., \& Srinivasan, S. S., (2003), "E-satisfaction and E-loyalty: A contingency framework", Psychology and Marketing, vol. 20, no. 2, pp. 123-138.

Anderson, E. W., \& Sullivan, M. W., (1993), "The antecedents and consequences of customer satisfaction for firms", Marketing Science, vol. 12, no. 2, pp. 125-143.

Andriyani, I. N., Wibowo, L. A., Novalita, D. P., Rahayu, W. P., Kusumojanto, D. D., Sulistyowati, R., \& Sudarwanto, T., (2017), "Dominant factor analysis of customer perceived value which effect on customer retention", The 1st International Conference on Economics and Business 2017 (UNICEB), Retrieved from http://digilib.unimed.ac. $\mathrm{id} / \mathrm{id} / \mathrm{eprint} / 28238$

Bagga, T., \& Bhatt, M., (2013), "A study of intrinsic and extrinsic factors influencing consumer buying behaviour online", Asia-Pacific Journal of Management Research and Innovation, vol. 9, no. 1, pp. 77-90.

Bauer, H. H., Falk, T., \& Hammerschmidt, M., (2006), "eTransQual: A transaction processbased approach for capturing service quality in online shopping", Journal of Business Research, vol. 59, no. 7, pp. 66-875.

Baumgarth, C., (2008), "Integrated model of marketing quality (MARKET-Q) in the B-to-B sector", Journal of Business Market Management, vol. 2, no. 1, pp. 41-57.

Beauchamp, M. B., \& Ponder, N., (2010), "Perceptions of retail convenience for in - store and online shoppers", The Marketing Management Journal, vol. 20, no. 1, pp. 49 - 65.

Bennett, R., Härtel, C. E., \& McColl-Kennedy, J. R., (2005), "Experience as a moderator of involvement and satisfaction on brand loyalty in a business-to-business setting", Industrial Marketing Management, vol. 34, no. 1, pp. 97-107. 
Berraies, S., Yahia, K. B., \& Hannachi, M. (2017), "Identifying the effects of perceived values of mobile banking applications on customers", International Journal of Bank Marketing, vol. 35, no. 6, pp. 1018-1038.

Berry, L. L., Seiders, K., \& Grewal, D., (2002), "Understanding service convenience", Journal of Marketing, vol. 66, no. 3, pp. 1-17.

Biedenbach, G., Bengtsson, M., \& Marell, A., (2015), "Brand equity, satisfaction, and switching costs: An examination of effects in the business-to-business setting", Marketing Intelligence and Planning, vol. 33, no. 2, pp. 164-178.

Biscaia, A. R., Rosa, M. J., Moura e Sa, S., P., \& Sarrico, C. S., (2017), “Assessing customer satisfaction and loyalty in the retail sector", International Journal of Quality and Reliability Management, vol. 34, no. 9, pp. 1508-1529.

Bi, Y., \& Kim, I. (2020), "Older travellers' e-loyalty: The roles of service convenience and social presence in travel websites", Sustainability, vol. 12, no. 1, pp. 410.

Blackwell, R. D., Miniard, P. W., \& Engel, J. F., (2001), Consumer behaviour, SouthWestern Thomson Learning, Ohio.

Bluedorn, A. C., (1982), "The theories of turnover: Causes, effects, and meaning", Research in the Sociology of Organizations, vol. 1, no. 1, pp. 75-128.

Calvo-Porral, C., \& Nieto-Mengotti, M., (2019), "The moderating influence of involvement with ICTs in mobile services", Spanish Journal of Marketing-ESIC, vol. 23, no. 1, pp. 25-43.

Capistrano, E. P., (2013), "Investigating product involvement issues for mobile phone services: A study of Filipino mobile phone users", Philippine Management Review, vol. 20, pp. 1-6.

Cardozo, R., (1965), "An experimental study of consumer effort, expectations and satisfaction", Journal of Marketing Research, vol. 2, no. 3, pp. 244-249.

Chadwick, C., \& Piartrini, P. S., (2019), "Product quality, convenience and brand loyalty: A case study of silver queen's adolescent consumers", 12th International Conference on Business and Management Research (ICBMR 2018), Retrieved from https://doi.org/10. 2991/icbmr-18.2019.19

Chai, C. T., (2019), "Intercepting stimulus-organism-response model, theory of planned behaviour and theory of expectancy confirmation in the study of smartphone consumer behaviour: A Thai university student perspective", Asia Pacific Journal of Religions \& Cultures, vol. 3, no. 2, pp. 27-48.

Cham, T. H., \& Easvaralingam, Y., (2012), "Service quality, image and loyalty towards Malaysian hotels", International Journal of Services, Economics and Management, vol. 4 no. 4 , pp. 267-281.

Cham, T. H., Lim, Y. M., \& Aik, N. C., (2015), "A study of brand image, perceived service quality, patient satisfaction and behavioural intention among the medical tourists", Global Journal of Business and Social Science Review, vol. 2 no. 1, pp. 14-26.

Cham, T. H., Lim, Y. M., Aik, N. C., \& Tay, A. G. M., (2016), "Antecedents of hospital brand image and the relationships with medical tourists' behavioural intention", International Journal of Pharmaceutical and Healthcare Marketing, vol. 10 no. 4, pp. 412-431.

Cham, T. H., Ng, C. K. Y., Lim, Y. M., \& Cheng, B. L. (2018), "Factors influencing clothing interest and purchase intention: a study of generation $\mathrm{Y}$ consumers in Malaysia", The International Review of Retail, Distribution and Consumer Research, vol. 28 no. 2, pp. 174-189.

Chang, C. C., Yan, C. F., \& Tseng, J. S., (2012), "Perceived convenience in an extended technology acceptance model: Mobile technology and English learning for college students", Australasian Journal of Educational Technology, vol. 28, no. 5, pp. 809-826.

Chao, R. F., \& Chen, H. F. (2016), "The effect of product involvement on the relationship between electronic word-of-mouth and purchase intention: The cross-cultural comparison between Taiwan and Mainland China", Journal of Global Business Management, vol. 12, no. 1, pp. 121-131. 
Chattha, M. N., Naqi, A., \& Haroon, A. (2016), "The impact of perceived quality, value and loyalty on the customer retention in the telecommunications sector of Pakistan", International Journal of Online Marketing Research, vol. 2, no. 2, pp. 25-31.

Chawla, D., \& Joshi, H. (2018), "The moderating effect of demographic variables on mobile banking adoption: An empirical investigation", Global Business Review, vol. 19, no. 3, pp. 90-113.

Cheah, J. H., Ting, H., Cham, T. H., \& Memon, M. A., (2019), "The effect of selfie promotion and celebrity endorsed advertisement on decision-making processes: A model comparison", Internet Research, vol. 29 no. 3, pp. 552-577.

Chen, K. H., Chang, F. H., Chen, Y. L., \& Chen, P. M., (2019), "The relationships between corporate credibility, service convenience, and consumers' use intentions: Toward ticketing apps for low-cost carriers", Sustainability, vol. 11, no. 3, pp. 810.

Cheng, B. L., Cham T. H., Micheal, D., \& Lee, T. H., (2019), "Service innovation: Building a sustainable competitive advantage in higher education", International Journal of Services, Economics and Management, vol. 10 no. 4, 289-309.

Cheng, B. L., Mansori, S., \& Cham, T. H., (2014), "The associations between service quality, corporate image, customer satisfaction, and loyalty: Evidence from the Malaysian hotel industry", Journal of Hospitality Marketing \& Management, vol. 23 no. 3, pp. 314-326.

Cheng, B. L., Mansori, S., Chuan, G. C., \& Imrie, B. C., (2017), "Hotel service recovery and service quality: Influences of corporate image and generational differences in the relationship between customer satisfaction and loyalty", Journal of Global Marketing, vol. 30 no. 1 , pp. $42-51$.

Chen-Yu, J., Kim, J., \& Lin, H. L., (2017), "Antecedents of product satisfaction and brand satisfaction at product receipt in an online apparel shopping context", Journal of Global Fashion Marketing, vol. 8, no. 3, pp. 207-219.

Chevalier, J. A., Dover, Y., \& Mayzlin, D., (2018), "Channels of impact: User reviews when quality is dynamic and managers respond", Marketing Science, vol. 37, no. 5, pp. 688709.

Choi, I. Y., Moon, H. S., \& Kim, J. K., (2019), “Assessing personalized recommendation services using expectancy disconfirmation theory", Asia Pacific Journal of Information Systems, vol. 29, no. 2, pp. 203-216.

Cimino, K., "The need for speed", Retrieved from http://siliconvalley.internet.com/news

Collier, J. E., \& Kimes, S. E., (2012), "Only if it is convenient: Understanding how convenience influences self-service technology evaluation", Journal of Service Research, vol. 16, no. 1, pp. 39-51.

Connelly, B. L., Lee, K. B., Tihanyi, L., Certo, S. T., \& Johnson, J. L., (2019), "Something in common: Competitive dissimilarity and performance of rivals with common shareholders", Academy of Management Journal, vol. 62, no. 1, pp. 1-21.

Consiglio, I., \& Van Osselaer, S. M., (2019), "The devil you know: Self-esteem and switching responses to poor service", Journal of Consumer Research, vol. 46, no. 3, pp. 590-605.

Darley, W. K., \& Luethge, D. J., (2019), "Service value and retention: Does gender matter?", Journal of Retailing and Consumer Services, vol. 48, pp. 178-185.

D'Arrigo, F., \& Fachinelli, A. C., (2014, June), "Crowdsourcing for sustainable growth: A Brazilian company case", 9th International Forum on Knowledge Asset Dynamics, Matera, Italy

Dick, A. S., \& Basu, K., (1994), "Customer loyalty: Toward an integrated conceptual framework", Journal of the Academy of Marketing Science, vol. 22, no. 2, pp. 99-113.

Ding, Y., Keh, H., (2016), "A re-examination of service standardization versus customization from the consumer's perspective", Journal of Services Marketing, vol. 30 no. 1, pp. 1628.

Dodds, W. B., Monroe, K. B., \& Grewal, D., (1991), "Effects of price, brand and store information on buyers' product evaluations", Journal of Marketing Research, vol. 28, no. 3, pp. 307-319.

Drezner, W., (2002), A balanced perspective on brands, McMillan, Baringstoke. 
Dunuwille, V. M., \& Pathmini, M. G. S., (2016), "Brand image and customer satisfaction in mobile phone market: Study based on customers in Kandy district", Journal of Business Studies, vol. 3, no. 1. pp. 1-98.

Dhurup, M., Surujlal, J., \& Redda, E., (2014), "Customer perceptions of online banking service quality and its relationship with customer satisfaction and loyalty", Mediterranean Journal of Social Sciences, vol. 5, no. 8, pp. 72-80.

Eggert, A., \& Ulaga, W. (2002), "Customer perceived value: A substitute for satisfaction in business markets", Journal of Business and Industrial Marketing, vol. 7, no. 2-3, pp. $107-118$.

Eshghi, A., Haughton, D., \& Topi, H. (2007), "Determinants of customer loyalty in the wireless telecommunications industry", Telecommunications Policy, vol. 31, no. 2, pp. 93-106.

Eum, S. W., Ahn, C. O., Rhim, H. S., (2019), "The impact of customization of tv home shopping mobile applications on service quality and customer loyalty", Journal of the Korean Society for Quality Management, vol. 47, no. 2, pp. 255-269.

Fan, L., \& Suh, Y. H., (2014), "Why do users switch to a disruptive technology? An empirical study based on expectation-disconfirmation theory", Information \& Management, vol. 51, no. 2, pp. 240-248.

Fornell, C., \& Larcker, D. F., (1981), "Evaluating structural equation models with unobservable variables and measurement error", Journal of Marketing Research, vol. 18 , no.1, pp. 39-50.

Gao, L. L., \& Waechter, K. A., (2017), "Examining the role of initial trust in user adoption of mobile payment services: An empirical investigation", Information Systems Frontiers, vol. 19 , no. 3, pp. 525-548.

Glynn, M. S., (2010), "The moderating effect of brand strength in manufacturer-reseller relationships", Industrial Marketing Management, vol. 39, no. 8, pp. 1226-1233.

Grant, D., Juntunen, J., Juga, J., \& Juntunen, M., (2014), "Investigating brand equity of thirdparty service providers", Journal of Services Marketing, vol. 28, no. 3, pp. 214-222.

Grewal, D., Monroe, K. B., \& Krishnan, R. (1998), "The effects of price-comparison advertising on buyers' perceptions of acquisition value, transaction value, and behavioural intentions", Journal of Marketing, vol. 62, no. 2, pp. 46-59.

Gupta, S., \& Kim, H. W. (2007), "The moderating effect of transaction experience on the decision calculus in on-line repurchase", International Journal of Electronic Commerce, vol. 12, no. 1, pp. 127-158.

Hair, J. F., Black, W. C., Babin, B. J., Anderson, R. E., \& Tatham, R. L., (2010), Multivariate data analysis, Pearson, London.

Halstead, D., Hartman, D., \& Schmidt, L. S., (1994), "Multi source effects on the satisfaction formation process", Journal of the Academy of Marketing Science, vol. 22, no. 2, pp. 114-129.

Han, S. L., \& Sung, H. S., (2008), "Industrial brand value and relationship performance in business markets: A general structural equation model", Industrial Marketing Management, vol. 37, no. 7, pp. 807-818.

Harrigan, P., Evers, U., Miles, M. P., \& Daly, T. (2018), "Customer engagement and the relationship between involvement, engagement, self-brand connection and brand usage intent", Journal of Business Research, vol. 88, pp. 388-396.

Harris, L. C., \& Goode, M. M., (2004), "The four levels of loyalty and the pivotal role of trust: A study of online service dynamics", Journal of Retailing, vol. 80, no. 2, pp. 139158.

Hayes, A. F., (2013), Introduction to mediation, moderation, and conditional process analysis: A regression-based approach, The Guilford Press, New York.

Hayes, A. F., Montoya, A. K., \& Rockwood, N. J., (2017), "The analysis of mechanisms and their contingencies: PROCESS versus structural equation modelling", Australasian Marketing Journal, vol. 25, no. 1, pp. 76-81.

Helin, C., (2014), Dances with dependency: Out of poverty through self-reliance, Open Road Integrated Media Inc, New York. 
Hill, D. J., (1985), "Satisfaction and consumer services", Advances in Consumer Satisfaction, vol. 13, pp. 311-315.

Hsu, C. L., Lin, Y. H., Chen, M. F., \& Suraphatchara, K., (2019), "Understanding foreign students' continuance intention toward mobile telecommunication service: An integrative theoretical model", International Journal of Electronic Commerce Studies, vol. 9 , no. 2 , pp. 93-118.

Huang, L. J., Mou, J., See-To, E. W. K., Kim, J. K., (2019), "Consumer perceived value preferences for mobile marketing in China: A mixed method approach", Journal of Retailing and Consumer Services, vol. 48(C), pp. 70-86.

Hung, S. Y., Yu, A. P. I., \& Chiu, Y. C., (2018), "Investigating the factors influencing small online vendors' intention to continue engaging in social commerce", Journal of Organizational Computing and Electronic Commerce, vol. 28, no. 1, pp. 9-30.

Jih, W. J., (2007), "Effects of consumer-perceived convenience on shopping intention in mobile commerce: An empirical study", International Journal of E-Business Research, vol. 3, no. 4, pp. 33-48.

Ji, F., \& He, Y. R. (2013), "Study on the relationships among customer satisfaction, brand loyalty and repurchase intention", Journal of Theoretical and Applied Information Technology, vol. 49, no. 1, pp. 180-186.

Jin, B. H., \& Park, J. Y. (2006), The moderating effect of online purchase experience on the evaluation of online store attributes and the subsequent impact on market response outcomes, in Pechmann, C., \& Price, L. (Eds.), Advances in Consumer Research, vol. 33, pp. 203-211.

Indiani, N. L. P., \& Fahik, G. A., (2020), "Conversion of online purchase intention into actual purchase: the moderating role of transaction security and convenience", Business: Theory and Practice, vol. 21, no. 1, pp. 18-29.

Iqbal, M. S., Hassan, M. U., \& Habibah, U. (2018), "Impact of self-service technology (sst) service quality on customer loyalty and behavioural intention: The mediating role of customer satisfaction", Cogent Business \& Management, vol. 5, pp. 1-23.

Jayanti, R., \& Jackson, A. (1991), "Service satisfaction: An exploratory investigation of three models", Advances in Consumer Research, vol. 18, no. 1, pp. 603-610.

Jumiati, S., \& Norazah, M. S., (2015), "Young consumers' insights on brand equity: Effects of brand association, brand loyalty, brand awareness, and brand image", International Journal of Retail and Distribution Management, vol. 43, no. 3, pp. 276-292.

Kajenthiran, K., Rajumesh, S., \& Umanakenan, R. (2018), "The impact of e-enabled banking services on customer loyalty: evidence from the Sri Lankan context", EPRA International Journal of Research and Development (IJRD), vol. 3, no. 8, pp. 1-9.

Kang, D. S., Park, M. J., Lee, D. H., \& Rho, J. J., (2017), "Mobile services with handset bundling and governmental policies for competitive market", Telematics and Informatics, vol. 34, no. 1, pp. 323-337.

Karjaluoto, H., Shaikh, A. A., Saarijärvi, H., \& Saraniemi, S. (2019), "How perceived value drives the use of mobile financial services apps", International Journal of Information Management, vol. 47, pp. 252-261.

Karani, K. G., \& Fraccastoro, K. (2010), "Resistance to brand switching: The elderly consumer", Journal of Business and Economics Research, vol. 8, no. 12, pp. 77-83.

Kaura, V., Prasad, C. S. D., \& Sharma, S., (2015), "Service quality, service convenience, price and fairness, customer loyalty, and the mediating role of customer satisfaction", International Journal of Bank Marketing, vol. 33, no. 4, pp. 404-422.

Keaveney, S. M., (1995), "Customer switching behaviour in service industries: An exploratory study", Journal of Marketing, vol. 59, no. 2, pp. 71-82.

Kim, J. M., \& Choi, S. B., (2019), "Social commerce service quality and word-of-mouth intention: An application of the expectation-disconfirmation theory,", Chungnam National University Institute of Management Economics Management Economics Research Management Economic Research, vol. 41, no. 4, pp. 47-73.

Kimmel, A., \& Kitchen, P. (2014), "Word of mouth and social media", Journal of Marketing Communications, vol. 20, no. 1-2, pp. 2-4. 
Konalingam, K., Ratnam, U., Sivapalan, A., \& Naveen, M. (2017), "Enhancing customer loyalty through e-banking practices", Business Management and Strategy, vol. 8, no. 2, 45-66.

Kumar, R., Sachan, A., \& Mukherjee, A. (2017), "Qualitative approach to determine user experience of e-government services", Computers in Human Behaviour, vol. 71, pp. 299-306.

Kuo, N. T., Chang, K. C., Chen, M. C., \& Hsu, C. L., (2012), "Investigating the effect of service quality on customer post-purchasing behaviours in the hotel sector: The moderating role of service convenience", Journal of Quality Assurance in Hospitality \& Tourism, vol. 13, no. 3, pp. 212-234.

Lai, S. L., Pham, H. H., Nguyen, H. K. T., Nguyen, T. C., \& Le, A. V. (2019), “Toward sustainable overseas mobility of Vietnamese students: Understanding determinants of attitudinal and behavioural loyalty in students of higher education", Sustainability, vol. 11 , no. 2 , pp. 282.

Larson, R. C., (1987), "OR forum-perspectives on queues: Social justice and the psychology of queueing", Operations Research, vol. 35, no. 6, pp. 895-905.

Laurent, G., \& Kapferer, J. N., (1985), "Measuring consumer involvement profiles", Journal of Marketing Research, vol. 22, no. 1, pp. 41-53.

Lee, J. M., Lee, B. H., \& Rha, J. Y., (2019), "Determinants of mobile payment usage and the moderating effect of gender: Extending the UTAUT model with privacy risk", International Journal of Electric Commerce Studies, vol. 10, no. 1, pp. 43-64.

Lee, K. Y., Hsu, Y. C., \& Fu, S. H., (2014), "The effects of service convenience, satisfaction, commitment on loyalty to retail service brand”, 朝陽商管評論, vol. 13, no. 2, pp. 4367.

Lemon, K. N., \& Verhoef, P. C., (2016), "Understanding customer experience throughout the customer journey", Journal of Marketing, vol. 80, no. 6, pp. 69-96.

Leppaniemi, M., Karjaluoto, H., \& Saarijarvi, H., (2017), "Customer perceived value, satisfaction, and loyalty: The role of willingness to share information", The International Review of Retail, Distribution and Consumer Research, vol. 27, no. 2, pp. 164-188.

Liebana-Cabanillas, F., Alonso-Dos-Santos, M., \& Soto-Fuentes, Y., (2017). "Unobserved heterogeneity and the importance of customer loyalty in mobile banking", Technology Analysis \& Strategic Management, vol. 29, no. 9, pp. 1015-1032.

Liébana-Cabanillas, F., Sánchez-Fernández, J., \& Muñoz-Leiva, F., (2014), “The moderating effect of experience in the adoption of mobile payment tools in virtual social networks: The M-payment Acceptance Model in Virtual Social Networks (MPAM-VSN)", International Journal of Information Management, vol. 34, no. 2, pp. 151-166.

Lien, C. H., Cao, Y., \& Zhou, X. (2017), "Service quality, satisfaction, stickiness, and usage intentions: An exploratory evaluation in the context of WeChat services", Computers in Human Behaviour, vol. 68, pp. 403-410.

Lim, Y. M., \& Cham, T. H., (2015), "A profile of the Internet shoppers: Evidence from nine countries", Telematics and Informatics, vol. 32 no. 2, pp. 344-354

Lim, Y. M., Cham, T. H., \& Sia, B. C., (2018), "Medical tourists' behavioural intention in relation to motivational factors and perceived image of the service providers", International Academic Journal of Organizational Behaviour and Human Resource Management, vol. 5 no. 3, pp. 1-16.

Ling, A. J., Yang, Z., \& Jun, M., (2013), "Measuring consumer perceptions of online shopping convenience", Journal of Service Management, vol. 24, no. 2, pp. 191-214.

MacKinnon, D. P., Coxe, S., \& Baraldi, A. N., (2012), "Guidelines for the investigation of mediating variables in business research", Journal of Business and Psychology, vol. 27, no. 1 , pp. 1-14.

Mahapatra, S., (2017), "Mobile shopping among young consumers: An empirical study in an emerging market", International Journal of Retail and Distribution Management, vol. 45, no. 9, pp. 930-949. 
Malaysian Communications and Multimedia Commission (MCMC), (2016), "3Q16 communications and multimedia facts \& figures, Retrieved from https://www.mcmc.g ov.my/skmmgovmy/media/General/pdf/3Q16-infog.pdf

Marquez, C., Gramaglia, M., Fiore, M., Banchs, A., Ziemlicki, C., \& Smoreda, Z., (2017), "Not all apps are created equal: analysis of spatiotemporal heterogeneity in nationwide mobile service usage", CoNEXT '17: Proceedings of the 13th International Conference on emerging Networking Experiments and Technologies, pp. 180-186.

Mat, A. S. A., Wan, J. W. J., \& Adeyemi, A. A., (2018), "Using expectation and confirmation theory to determine customer loyalty among post-paid users", Indian Journal of Public Health Research \& Development, vol. 9, no. 11, pp. 1283-1293.

Memon, M. A., Ting, H., Ramayah, T., Chuah, F., \& Cheah, J. H., (2017), "A review of the methodological misconceptions and guidelines related to the application of structural equation modelling: A Malaysian scenario", Journal of Applied Structural Equation Modelling, vol. 1, no. 1, pp. i-xiii.

Mittal, B., \& Lee, M. S., (1989), “A causal model of consumer involvement”, Journal of Economic Psychology, vol. 10, no. 3, pp. 363-389.

Morgan, R. M., \& Hunt, S. D., (1994), "The commitment-trust theory of relationship marketing", Journal of Marketing, vol. 58, no. 3, pp. 20-38.

Mourtzis, D., Doukas, M., \& Vandera, C., (2014), "Smart mobile apps for supporting product design and decision-making in the era of mass customization", International Journal of Computer Integrated Manufacturing, vol. 30, no. 7, pp. 690-707.

Nazir, B., Ali, M., Jamil, M., (2016), "The impact of brand image on the customer retention: A mediating role of customer satisfaction in Pakistan", International Journal of Business and Management Invention, vol. 5, no. 3, pp. 56-61.

Ngobo, P. V., (2017), "The trajectory of customer loyalty: An empirical test of Dick and Basu's loyalty framework", Journal of Academy of Marketing Science, vol. 45, no. 2, pp. 229-250.

Nguyen, N., \& Leblanc, G., (2001), "Corporate image and corporate reputation in customers' retention decisions in services", Journal of Retailing and Consumer Services, vol. 8, no. 4, pp. 227-236.

Nguyen, N., \& Nguyen, H., (2019), "How do Product Involvement and prestige sensitivity affect price acceptance on the mobile phone market in Vietnam?", Journal of Asia Business Studies, vol. ahead-of-print, no. ahead-of-print.

Nikolaev, M. A., Makhotaeva, M. Y., Malyshev, D. P., Malyuk, V. I., (2017), "Corporate strategy for enterprises of telecommunication services sector in Russia", Quality Management, Transport and Information Security, Information Technologies, pp. 560567.

Ofori, K. S., Boakye, K., \& Narteh, B., (2018), "Factors influencing consumer loyalty towards 3G mobile data service providers: Evidence from Ghana", Total Quality Management \& Business Excellence, vol. 29, no. 5-6, pp. 580-598.

Oghuma, A. P., Libaque-Saenz, C. F., Wong, S. F., \& Chang, Y. H., (2016), “An expectationconfirmation model of continuance intention to use mobile instant messaging", Telematics and Informatics, vol. 33, no. 1, pp. 34-47.

Oliver, R. L., (1980), "A cognitive model of the antecedents of satisfaction decisions", Journal of Marketing Research, vol. 17, no. 4, pp. 46-49.

Oliver, R. L., (1977), "Effect of expectation and disconfirmation on post exposure product evaluations: An alternative interpretation", Journal of Applied Psychology, vol. 62, no. 4, pp. 480-486.

Oliver, R. L., (1999), “Whence consumer loyalty?”, Journal of Marketing, vol. 63, pp. 33-44.

Othman, A. K., Hassan, L. F. A., Ibrahim, M. A. M., Saripin, M. S., Sapuan, N. S. A., \& Roslan, Z. N., (2020), "Factors that influence customer loyalty in using e-commerce", Journal of Islamic Management Studies, vol. 2, no. 20, pp. 45-58.

Oyeniyi O., \& Abiodun A. J., (2010), "Switching cost and customers loyalty in the mobile phone market: The Nigerian experience", Business Intelligence Journal, vol. 3, no. 1, pp. 111-121. 
Pansari, A., \& Kumar, V., (2017), "Customer engagement: The construct, antecedents, and consequences", Journal of the Academy of Marketing Science, vol. 45, no. 3, pp. 294311.

Peña, A. I. P., Jamilena, D. M. F., \& Molina, M. A. R., (2016), "The effects of perceived value on loyalty: The moderating effect of market orientation adoption", Service Business, vol. 11, no. 1, pp. 1-24.

Pham, N. T., (2011), "Using service convenience to reduce perceived cost", Marketing Intelligence \& Planning, vol. 29, no. 5, pp. 473-487.

Pham, Q. T., Tran, X. P., Misra, S., Maskeliūnas, R., \& Damaševičius, R., (2018), "Relationship between convenience, perceived value, and repurchase intention in online shopping in Vietnam", Sustainability, vol. 10, no. 1, p. 156.

Pirc, M., (2006), "Mobile service and phone as consumption system: The impact on customer switching", Proceedings of Helsinki Mobility Roundtable Sprouts: Working Papers on Information Systems, vol. 6, p. 33.

Pope, M., Pantages, R., Enachescu, N., Dinshaw, R., Joshlin, C., Stone, R., Austria, A., \& Seal, K. (2011), "Mobile payments: The reality on the ground in selected Asian countries and the United States", International Journal of Mobile Marketing, vol. 6, no. 2, pp. 88-104.

Quoquab, F., Abdullah, N. L., \& Mohammad, J., (2016), "Investigating the effects of consumer innovativeness, service quality and service switching costs on service loyalty in the mobile phone service context", Gadjah Mada International Journal of Business, vol. 18 , no. 1 , pp. 21.

Quoquab, F., Mohammad, J., Yasin, N., \& Abdullah, N., (2018), "Antecedents of switching intention in the mobile telecommunications industry: A partial least square approach", Asia Pacific Journal of Marketing and Logistics, Vol. 30 No. 4, pp. 1087-1111.

Raj, M. P. M., \& Roy, S., (2015), "Impact of brand image on consumer decision-making: A study on high-technology products", Global Business Review, vol. 16, no. 3, pp. 463477.

Rajamma, R. K., Paswan, A. K., \& Hossain, M. M., (2009), "Why do shoppers abandon shopping cart? Perceived waiting time, risk, and transaction inconvenience", Journal of Product and Brand Management, vol. 18, no. 3, pp. 188-197.

Reichheld, F. F., (2003), "The one number you need to grow", Harvard Business Review, vol. 81 , no. 12 , pp. 46-54.

Rokonuzzaman, M., Harun, A., Al-Emran, E., \& Prybutok, V. R., (2020), “An investigation into the link between consumer's product involvement and store loyalty: The roles of shopping value goals and information search as the mediating factors", Journal of Retailing and Consumer Services, vol. 52, pp. 1-11.

Sabine, B., Klose, S., \& Ettinger, A., (2017), "Linking service convenience to satisfaction: Dimensions and key moderators", Journal of Services Marketing, vol. 31, no. 6, pp. 527-538.

Sanchez, J., Callarisa, L., Rodriguez, R. M., \& Moliner, M. A., (2006), "Perceived value of the purchase of a tourism product", Tourism management, vol. 27, no. 3, pp. 394-409.

Sarkas, J. G., \& Sarkas, A., (2019), "Young adult consumers' involvement in branded smartphone-based service app", Information Technology \& People, vol. 32, no. 6, pp. 1608-1632.

Sathish, M., Kumar, K., \& Jeevanantham, V., (2011), "A study on consumer switching behaviour in cellular service provider: A study with reference to Chennai”, Far East Journal of Psychology and Business, vol. 2, no. 2, pp. 71-81.

Seiders, K., Berry, L. L., \& Gresham, L. G., (2000), "Attention, retailers! How convenient is your convenience strategy?", MIT Sloan Management Review, vol. 41, no. 3, pp. 79-89.

Sirdeshmukh, D., Singh, J., \& Sabol, B., (2002), "Customer trust, value, and loyalty in relational exchanges", Journal of Marketing, vol. 66, no. 1, pp. 15-37.

So, K. K. F., King, C., Sparks, B. A., \& Wang, Y., (2016), "The role of customer engagement in building consumer loyalty to tourism brands", Journal of Travel Research, vol. 55, no. 1, pp. 64-78. 
Sun, Y. M., Cheng, Y., \& Cui, H. Y., (2016), "The effects of app store involvement on app downloading intention", 2016 13th International Conference on Service Systems and Service Management, pp. 1-15.

Sweeney, J. C., \& Soutar, G. N., (2001), "Consumer perceived value: The development of a multiple item scale", Journal of Retailing, vol. 77, no. 2, pp. 203-220.

Swoboda, B., Berg, B., Schramm-Klein, H., \& Foscht, T., (2013), "The importance of retail brand equity and store accessibility for store loyalty in local competition", Journal of Retailing and Consumer Services, vol. 20, no. 3, pp. 251-262.

Tahir, M., Batool, S., (2018), "The effects of customer relationship management programs on customer retention mediated by firm reputation in telecom sector", City University Research Journal, vol. 8, no. 1, pp. 90-102.

Tan, C. C., (2016), Towards a phenomenological theory of corporate social responsibility and its spirited services, IMRF Publication House, India.

Temkin Group, (2012), "Temkin Group Insight Report - The ROI of customer experience: Analysis shows high correlation between customer experience and loyalty", Retrieved from http://www.oracle.com/us/solutions/customer-experience/roiofcx-temkingroup-17 15500.pdf.

The Edge, (2019), "Mixed results for telco sector amid moderating regulatory pressures", Retrieved from https://www.theedgemarkets.com/article/mixed-results-telco-sectoramid-moderating-regulatory-pressures

The Sun Daily (2019), "Telco sector continues to see intense competition", Retrieved from https://www.thesundaily.my/business/telco-sector-continues-to-see-intensecompetition-EI648457

Ting, H., Fam, K-S., Cheah, J., Richard, J. E., \& Xing, N., (2019), "Ethnic food consumption intention at the touring destination: The national and regional perspectives using multigroup analysis", Tourism Management, vol. 71, pp. 518-29.

Tung, F., (2013), "Customer satisfaction, perceived value and customer loyalty: The mobile services industry in China", African Journal of Business Management, vol. 7, no. 18, pp. 1730-1737.

Umashankar, N., Bhagwat, Y., \& Kumar, V., (2017), "Do loyal customers really pay more for services?", Journal of the Academy of Marketing Science, vol. 45, pp. 807-826.

Veloutsou, C., Daskou, S., \& Daskou, A., (2004), "Are the determinants of bank loyalty brand specific?", Journal of Financial Services Marketing, vol. 9, no. 2, pp. 113-125.

Vera, J., \& Trujillo, A., (2017), "Searching most influential variables to brand loyalty measurements: An exploratory study", Contaduría y Administración, vol. 62, no. 2, pp. 600-624.

Walters, C. G., (1974), Consumer behaviour: Theory and practice, R. D. Irwin, Homewood.

Wan, J. F., Yi, M. L., Li, D., Zhang, C. H., Wang, S. Y., \& Zhou, K. L., (2016), "Mobile services for customization manufacturing systems: An example of industry 4.0", IEEE Access, vol. 99, pp. 8977-8986.

Wijaya, B. S., "Branderpreneurship: Brand development-based entrepreneurship", International Conference on Business and Communication (ICBC), Jakarta, Indonesia.

Wong, W. T., \& Chang, W. H., (2014), "A study of virtual product consumption from the expectancy disconfirmation and symbolic consumption perspectives", Information Systems Frontiers, vol. 16, no. 5, pp. 887-908.

Yi. Y., (1990), A critical review of consumer satisfaction, in V.A. Zeithaml (Ed.), Review of Marketing, American Marketing Association, Chicago, pp. 68-123.

Yang, H. T., Yu, J., Zo, H. J., \& Choi, M. K., (2016), "User acceptance of wearable devices: An extended perspective of perceived value", Telematics and Informatics, vol. 33, no. 2, pp. 256-269.

Yang, S., Song, Y., Chen, S., \& Xia, X., (2017), "Why are customers loyal in sharingeconomy services? A relational benefits perspective", Journal of Services Marketing, vol. 31, no. 1, pp. 48-62. 
Yüksel, A., \& Yüksel, F., (2008), Consumer satisfaction theories: A critical review. In: Tourist Satisfaction and Complaining Behaviour: Measurement, and Management Issues, in the Tourism and Hospitality Industry, Nova Science Publishers, New York.

Zaichkowsky, J. L., (1985), "Measuring the involvement construct", Journal of Consumer Research, vol. 12, no. 3, pp. 341-352.

Zeithaml, V. A., (1988), "Consumer perceptions of price, quality, and value: A means-end model and synthesis of evidence", Journal of Marketing, vol. 52, no. 3, pp. 2-22.

Zeithaml, V. A., Berry, L. L., \& Parasuraman, A., (1996), "The behavioural consequences of service quality", Journal of Marketing, vol. 60, no. 2, pp. 31-46.

Zhang, N., Zhou, Z. M., Su, C. T., \& Zhou, N., (2013), "How do different types of community commitment influence brand commitment? The mediation of brand attachment", Behaviour \& Social Networking, vol. 16, no. 11, pp. 836-842.

Zhu, Y., Freeman, S., \& Cavusgil, T., (2018), "Service quality delivery in a cross-national context”, International Business Review, vol. 27, no. 5, pp. 1022-1032. 